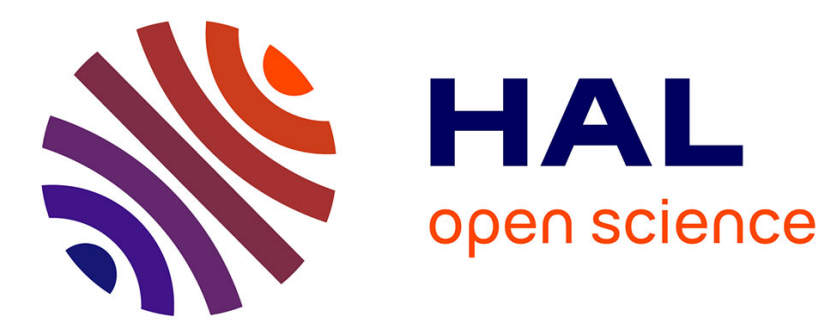

\title{
Does Mobile Money Affect Saving Behavior? Evidence from a Developing Country
}

Serge Ky, Clovis Rugemintwari, Alain Sauviat

\section{To cite this version:}

Serge Ky, Clovis Rugemintwari, Alain Sauviat. Does Mobile Money Affect Saving Behavior? Evidence from a Developing Country. 2017. hal-01360028v2

\section{HAL Id: hal-01360028 \\ https: / hal-unilim.archives-ouvertes.fr/hal-01360028v2}

Preprint submitted on 16 Nov 2017

HAL is a multi-disciplinary open access archive for the deposit and dissemination of scientific research documents, whether they are published or not. The documents may come from teaching and research institutions in France or abroad, or from public or private research centers.
L'archive ouverte pluridisciplinaire $\mathbf{H A L}$, est destinée au dépôt et à la diffusion de documents scientifiques de niveau recherche, publiés ou non, émanant des établissements d'enseignement et de recherche français ou étrangers, des laboratoires publics ou privés. 


\title{
Does mobile money affect saving behavior? \\ Evidence from a developing country
}

\author{
Serge Ky ${ }^{\text {a, }}$, Clovis Rugemintwari ${ }^{\text {a }}$ and Alain Sauviat ${ }^{\text {a }}$ \\ ${ }^{a}$ Université de Limoges, LAPE, 5 rue Félix Eboué, 87031 Limoges Cedex, France
}

(Forthcoming in The Journal of African Economies)

\begin{abstract}
We investigate whether the use of mobile money can help individuals build savings to face predictable and unpredictable life events. Studying the case of Burkina Faso, we use hand-collected data from individual responses to a survey we designed and conducted between May and June 2014. Our main results show that, although it is not possible to detect any correlation between using mobile money and saving for predictable events, it seems to increase the propensity of individuals to save for health emergencies. We also find robust evidence suggestive that using mobile money increases the propensity of disadvantaged groups such as rural, female, less educated individuals and individuals with irregular income to save for health emergencies. In our further investigations, we address the mechanisms underlying individual saving behavior. We find that safety and the possibility to transfer money within the sub-region associated with mobile money may be factors that increase the propensity of mobile money users to save for health emergencies. Overall, our results are in line with policymakers' agenda worldwide to increase financial outreach and improve financial inclusion by using mobile technologies. (JEL Classification D14, G23, O12)
\end{abstract}

Keywords: mobile money, savings, financial inclusion, sub-Saharan Africa, Burkina Faso

\footnotetext{
${ }^{1}$ This paper benefited from discussions with Philippe Rous, Isabelle Distinguin and Ruth Tacneng. We are grateful for their helpful suggestions and advice. We thank Idrissa M. Ouédraogo, Kassoum Zerbo, François Seck Fall, Denis Akouwerabou who were helpful in designing and conducting our survey. We also thank our discussants Jann Goedecke, Erwan Le Saout, Pauline Rossi and the participants at the 4th European Microfinance Research Conference, the $32^{\text {nd }}$ International Symposium on Money, Banking and Finance and the $64^{\text {th }}$ Annual Meeting of the French Economic Association for their helpful comments and discussions. Mamadou Diallo and Tidiane Ouédraogo from the BCEAO allowed us to access data on financial inclusion in West African Economic and Monetary Union (WAEMU); their helpful assistance is acknowledged as well. The usual disclaimer applies. Corresponding Author. Tel: + 33555 1492 51. Fax: 05551492 06. E-mail address : serge.ky@etu.unilim.fr
} 


\section{Introduction}

In developing countries, limited access to formal financial institutions makes individuals and households rely mainly on informal networks to build up savings. Such informal saving mechanisms include saving in livestock or jewels, saving at home "under a mattress", saving with a neighbor or, in a more organized way, participating in a Rotating Savings and Credit Associations $\left(\right.$ ROSCAs) ${ }^{2}$. However, these informal saving devices provide an insurance which is well known to be risky, inappropriate and incomplete. For instance, to deal with unexpected events such as health deterioration, which is very common in sub-Saharan Africa, it is crucial to have access to liquid assets to benefit from appropriate medical services. Holding too much cash is not an appropriate solution at least for two reasons. First, this way of saving is subject to theft or "taxes" by friends or relatives for assistance. Second, savers face self-control problems through "temptation goods" that make it difficult for them to postpone an important part of their consumption (Banerjee and Mullainathan, 2010).

Our paper is at the intersection of different strands of the literature addressing mobile money, saving patterns, formal financial access and usage. More specifically, our main goal in this paper is to examine the impact of using mobile money as a soft commitment device on individuals' saving behavior. This investigation is relevant to policy agendas of governments and international organizations which aim at improving people's lives by developing financial inclusion. The growing financial innovation of mobile money such as the use of a cell phone as an electronic wallet (e-wallet) allows individuals to transfer purchasing power by using simple short messaging services (SMS) technology and to store value through cash in and cash out functions. Moreover, mobile money users may deposit funds for free but are taxed for withdrawals and transfers. Thus, by storing value in their mobile money account, people are insured against theft and unneeded expenditures because of the withdrawal and transfer fees which encourage them to cash out or transfer money only when the need arises ${ }^{3}$. In fact, money transfers between users are not only a simple deposit-transfer-withdraw transaction but some users keep the mobile money as savings (Mbiti and Weil, 2013). However, the cost of transferring money from users of mobile money to

\footnotetext{
${ }^{1}$ Rotating Savings and Credit Association (ROSCA) is a saving group involving many parties who know one another that meets on a regular basis. At each meeting, group members make a fixed mandatory contribution which goes into a "pot" that is then assigned to one of the members. For more details, see Ambec and Treich (2007), Dupas and Robinson (2013b) and Smets (2000).

${ }^{3}$ Therefore, the withdrawal and money transfer fees serve as a soft commitment device.
} 
non-users is higher than the cost of withdrawals and debited to the user account. This pricing schedule may lead users to keep their mobile money or only transact with non-users in case of emergencies. Mobile money is also characterized by unique features that equip it with certain advantages such as mobiquity, affordability, speed, safety and security through a Personal Identification Number (PIN), especially the SIM card ${ }^{4}$, that allows to lock the mobile money account at anytime, everywhere and without the risk of falsification. By using mobile money, individuals can easily exchange cash for e-money or vice-versa with mobile money agents across the country. Once the deposit is made, they can either keep it safe in the mobile phone as savings or transfer the balance via SMS to any other mobile phone in the country or overseas ${ }^{5}$. The recipient does not need to have a mobile money subscription and the mobile phone can be registered on a competing network. It is hence essential for mobile money users to have convenient access to cash in/out options in order for them to convert their cash into electronic money and vice versa. Moreover, certified agents have to hold sufficient balance of electronic money or cash, allowing retail agents to rebalance their liquidity (convert electronic money into cash, and vice versa) to ensure the efficiency of users' cash in/out functions.

Mobile money has recently risen to the forefront of development agendas in less developed countries. Although considerable research has been conducted in this field, most of it has focused on the case of M-PESA in Kenya ${ }^{6}$. Key findings that emerge from these previous investigations show that mobile money adoption reduces monetary and security costs of transferring money compared to traditional means of money transfers such as the use of Western Union, MoneyGram, or transport companies (Mbiti and Weil, 2011). In a similar vein, it is shown that by reducing transaction costs, mobile money adoption has substantial impact on the size and the frequency of remittances that ultimately allows households to smooth consumption and share risk (Jack and Suri, 2014). Mas and Mayer (2011) suggest and describe how mobile money can be used to create a safe saving account where individuals can deposit small amounts of money for more immediate needs.

\footnotetext{
${ }^{4}$ The Subscriber Identification Module (SIM) card refers to a smart card inside mobile phones. It contains an encryption key that secures the user's PIN on entry. For more, see (Eijkman et al., 2010; Mbiti and Weil, 2011).

${ }^{5}$ Especially in Ivory Coast where a large community of Burkinabe lives. A recent study by Lonie et al. (2013) shows that there are about 6 millions of mobile money subscribers in Ivory Coast in December 2013. Mobile money is therefore an important channel which Burkinabe immigrants may use in order to send money at home.

${ }^{6}$ M-PESA was launched in 2007 and is considered as the most successful mobile money system in the world. Since its launch, M-PESA registration has grown exponentially from $21 \%$ in 2008 to $75 \%$ of the Kenyan adult population in November 2014 (The Economist, 2014). For more details, see CFSP (2013) and Jack and Suri (2011).
} 
Mas and Kumar (2008) describe how a mobile phone can be seen as an opportunity of delivering basic banking services to poor people who have less alternatives than rich people. In fact, a mobile phone can act as a virtual bank card by storing information about the user and the mobile money account into the subscriber identity module (SIM) card inside the phone. Thus, it can be used to initiate securely transactions request and authorization. Therefore, although it does not pay interest, storing mobile value in the phone provides the same benefits that a traditional bank saving account provides with an additional benefit in cash. Related to our investigation, Mbiti and Weil (2011) find that while M-PESA is mainly used for money transfers, it also serves as a storage of value by decreasing the use of informal saving mechanisms such as ROSCA. Along this line, Demombynes and Thegeya (2012) find empirically that individuals registered with M-PESA are more likely to save than those who are not registered with M-PESA. In a field experiment in Afghanistan Blumenstock, Callen and Koepke (2015) who show that the use of mobile money for salary payment results in cost savings for the employer, emphasize that it may have in the long term an impact on the total savings of employees. Other studies document analytically that people may prefer mobile money account to keep money for emergencies while for long-term savings, they would use tools that limit access to cash (such as bank accounts or participation into a ROSCA) (Mbarathi and Diga, 2014; Morawczynski and Pickens, 2009). In this paper, our aim is to empirically test these conjectures. We study the impact of mobile money adoption on individual saving behavior by distinguishing savings for immediate purposes (i.e. health shocks, financial shocks) from savings for long-term purposes which are rather predictable (i.e. to develop an activity).

Our choice to focus on savings cannot be overemphasized. Indeed, saving is one of the key aspects of financial practices that any individual has to assume himself. Savings help people manage vulnerabilities and build an asset base, which can be used to lessen the risk of incidence of adverse shocks (Hulme, Moore and Barrientos, 2009). Particularly in developing countries, people often face a variety of negative shocks related to ill-health or death of a family member which can overwhelm their means and hence hamper economic activity and development. This is why in such an environment, providing people with an appropriate saving technology can help them deal with unpredictable life events (Christen and Mas, 2009). In this regard, building on recent empirical 
findings by Dupas and Robinson (2013b) ${ }^{7}$, which show that simply providing a safe place to keep money is sufficient to increase preventative health savings, we investigate whether using mobile money can help individuals increase their propensity to save for health emergencies, particularly those with less access to formal financial instruments.

At the macroeconomic-level, saving rates are positively associated with future economic growth. Evidence, however, suggests that in less developed countries, people lack access to formal financial services (e.g. saving account), which hinders their propensity to save. The lack of banking infrastructure and its low coverage network as well as high transaction costs, financial illiteracy and the lack of information are often cited as the main causes of the low access to formal financial services (Allen et al., 2014; Dermish et al., 2012; Jack and Suri, 2014; Ondiege, 2010). The unbanked individuals are generally poor, live in rural area with precarious and irregular incomes, and often rely on microfinance and informal finance to realize their financial projects (Kendall, 2010; Mas and Mayer, 2011; Mas, 2010; Rutherford, 2002). Microfinance institutions play an important role in providing formal financial services to the excluded people (Ondiege, 2010). In many developing countries, they have made a critical contribution by providing first microcredits and later on microsavings and also by locating their branches in places neglected by banks. However, the cost of operating microfinance institutions remains very high leading to high transaction costs supported by customers. This is why people still need more access to appropriate financial products that meet their needs especially good saving and payment services including remittances and insurance (Beck et al., 2009; Karlan and Morduch, 2009).

Our paper contributes to the aforementioned literature in two main ways. First, our study is the first that empirically tests the impact of mobile money on saving patterns by distinguishing savings for unpredictable events and savings for anticipated events. More specifically, we examine whether mobile money users are more likely to save for health emergencies or save to develop an activity than mobile money non-users. Second, to the best of our knowledge the existent studies on mobile money only describe the potential impact of this new technology on poor people financial

\footnotetext{
${ }^{7}$ Dupas and Robinson (2013b) perform a field experiment on 771 individuals in rural Kenya to test the effects of four innovative commitment saving devices through the "mental accounting". The Safe Box, the Lockbox, the Health Savings Account and the Health Pot were provided to four groups to buildup savings for preventative and emergencies health expenses. They find that simply providing a safe place to save was sufficient to increase health savings by $66 \%$. They also report that earmarking was helpful when funds were put toward emergencies or for individuals that are frequently taxed by friends and relatives.
} 
management. Our detailed data set enables us to go further and test whether the use of mobile money has an impact on saving behavior of disadvantaged groups such as low and irregular incomes, rural, female and less educated. On the whole, the lack of empirical studies in this area may be due primarily to data scarcity (i.e. no readily available secondary databases) and costly collection of primary data. For our study, we use hand-collected data from a survey conducted in Burkina Faso, a country where many initiatives are increasingly implemented to improve the expansion of mobile money.

Using individual responses to a survey we conducted between May and June 2014 in Burkina Faso, we utilize the logistic model to study whether mobile money affects people saving behavior. Our main results show that using mobile money services is positively associated with the propensity of individuals to save for unpredictable events, such as health emergencies. We do not, however, detect any association between mobile money and savings for anticipated objectives. By taking into account the outreach, i.e. existing disparities in the access and usage of formal financial services, our results show that mobile money increases the propensity of rural, female, less educated individuals and individuals with irregular income to save for health emergencies. These results taken together have important policy implications. By helping individuals build their savings to face unanticipated events, facilitating mobile money adoption appears to be an important way to improve financial inclusion.

The remainder of the paper is organized as follows. In the next section, we discuss the research framework. Section 3 describes our survey design and data collection. It also provides background information on the adoption of mobile money and the state of existing financial services in Burkina Faso. In section 4 we present our model specification and follow this with the results in section 5. Section 6 presents the discussion of potential mechanisms through which mobile money can affect saving behavior and we conclude in section 7 .

\section{Research Framework}

Two distinguishing features arise from the existing literature (Batista and Vicente, 2016; Kendall, 2010; Mas, 2010; Mas and Mayer, 2011; Mbiti and Weil, 2011; Morawczynski and Pickens, 2009; Rutherford, 2002). First, despite the lack of easy access to formal financial services in developing countries, poor people manage to save although they mainly do so through informal 
mechanisms, and second the adoption of mobile money may or may not affect saving behavior. Generally, its impact on saving behavior may depend on two important aspects: the purpose of saving (unpredictable events, short term vs. predictable, long term) and the outreach based on exogenous characteristics (i.e. gender, location, education and incomes).

\subsection{Mobile money adoption and saving for unpredictable and predictable events}

In developing countries, people often have to rely on informal saving mechanisms to manage their finances, as an alternative, due to the lack of access to formal financial services such as saving accounts. Because of this, several initiatives have been undertaken either by private or government entities to promote branchless banking such as mobile money. In some cases though, as we discuss hereafter, informal saving mechanisms may fit the needs of the individuals to save for anticipated objectives and hence make less relevant the reliance on the innovation of mobile money.

For long term projects, informal saving mechanisms such as participating in savings groups (ROSCAs), or investing in land, jewels and livestock, may be considered convenient. Indeed, to deal with anticipated events like starting up or developing a business, people can easily sell their physical assets since the date of the event is preset. For individuals participating in ROSCAs, they can preset the startup date according to the date they are assigned to receive the pot, as many ROSCAs use a predetermined order to allocate the savings pot. Yet, these saving mechanisms involve high risk taking. For instance, some ROSCAs disband and often without warning. Moreover, holding illiquid assets expose individuals to loss or theft and assets depreciation (Christen and Mas, 2009; Mas, 2010; Morawczynski, 2009). In this context, we suppose that individuals may consider adopting mobile money as an alternative saving device because mobile money account is personal and relatively safe, and they can easily determine their own target to reach in order to realize their investment project. However, several studies show that planning for long term objectives requires less access to the money (Mbarathi and Diga, 2014; Morawczynski and Pickens, 2009). In the same vein, Dupas and Robinson (2013a) provide evidence that expanding savings access, especially bank accounts, increases business investment. Thus, using saving devices which restrict access to cash until a target date is attained would be more adequate to plan for anticipated objectives. Thereby, as mobile money increases access to cash, it may have 
less or no impact on saving for predictable events compared to saving for unanticipated events for which, as we argue below, mobile money may prove to be better-suited.

To deal with unpredictable events such as health emergencies, people need adequate saving instruments that facilitate access to cash. Selling land, jewels or animals quickly in response to adverse health shocks is not easy and may not always be reliable. Similarly, in the case where individuals participate in ROSCAs, since there is a typically predetermined order, it is impossible to access the money immediately when an emergency comes up. In such circumstances, some people turn to relatives for help. These relatives, however, may not have liquid savings and therefore would have to sell assets (Collins et al., 2009). Mobile money may thus be particularly prominent in this regard by providing easy access to cash for emergency purposes. This conjecture is supported by the findings of Dupas and Robinson (2013b) who show through a field experiment in Kenya that simply providing a safe place to keep money is sufficient to increase preventive health savings. This result highlights that to build savings for unpredictable events, individuals need a safe place which allows them to get back their money when the need arises. In this context, we expect that using mobile money should have a positive impact on individuals saving behavior for unanticipated events such as health emergencies. Some caution is, however, in order. The liquid savings option provided by the mobile money, accessible anywhere and anytime, could increase family assistance and hence, it may have a negative impact on individual savings. Moreover, the withdrawal tax feature of mobile money may help people resist unneeded expenditures on the one hand but it may discourage them to put money in their account and dismiss its effects on savings on the other hand. Our empirical investigation aims at determining which effect dominates over the other.

\subsection{Mobile money adoption and the "triple whammy"}

In their frequently cited book, The portfolios of the poor, Collins et al. (2009) highlight that in developing countries people not only have to cope with (1) low incomes but that these incomes are also (2) irregular and that (3) too few financial instruments are available to help individuals in their management. They term this the "triple whammy" . Given the huge disparities in access to formal financial services that exist depending, among other things, on the location, gender, income

${ }^{8}$ The "triple whammy": low incomes, irregularity; and a lack of tools (Collins et al. 2009, p.16). 
or education of the population, it is crucial to take this dimension into consideration while examining the impact of mobile money adoption on the saving behavior.

\section{a) Low, irregular vs. High, regular incomes}

In less developed countries where a significant fraction of the population lives under the national poverty line, poor people incomes are not just low, but also they are often irregular. Moreover, it is shown that poor individuals, unlike rich people, are more likely to save their small amount of money through a variety of informal mechanisms (Banerjee and Duflo, 2007; Chowa, Masa and Sherraden, 2012; Christen and Mas, 2009; Collins et al., 2009; Mas, 2010) despite their risky nature. Recent research, however, describes how individuals have increasingly turned to mobile money as a storage device to keep smaller amounts of money (Morawczynski, 2009). Moreover, Demombynes and Thegeya (2012) highlight that aside from this, mobile money serves as a saving device which ensures safety against the dangers of theft and which is inaccessible to relatives. Therefore one may expect that, in the presence of good saving tools such as mobile money which is reliable, safe and affordable, individuals with low and/or irregular incomes would be inclined to rely on it to build their savings.

\section{b) Low vs. High access to formal financial instruments}

The location (rural vs. urban), gender (female vs. male) and the level of education are key determinants of accessibility to formal financial services. Firstly, the breakdown of financial infrastructure shows disparities between rural and urban areas. In most sub-Saharan African countries rural areas are the most populated, representing $60 \%$ of the total African population but where the activities of commercial banks remain underdeveloped (Dupas et al., 2012; Mas, 2010; Ondiege, 2010). Almost all formal financial institutions are concentrated in urban areas leaving rural areas underserved. People living in rural areas vs. urban areas have less access to a wide range of financial services to cope up with life events, both anticipated and unanticipated. Mobile money can potentially help bridge this gap as a growing number of people uses this new technology as an alternative to traditional banking. Morawczynski (2009) shows that in Kenya, people living in urban areas are less likely to use their M-PESA account to save because they have formal saving 
mechanisms to meet their saving needs. Other arguments include the fact that people may need to keep their money into a bank account to build a relationship with the financial institution to access credit in the future. In urban areas, the impact of mobile money on individuals' saving patterns both unpredictable and predictable, should hence be minimal. Furthermore, Dupas et al. (2012) show that in rural Kenya the lack of formal bank accounts is a serious obstacle for people to save. In this context, we expect that providing individuals in rural areas with access to mobile money services may increase their propensity to save (Aker and Mbiti, 2010; Allen et al., 2014; Christen and Mas, 2009; Dupas and Robinson, 2013b).

Secondly, all else being equal, women remain comparatively more excluded from the financial sector and hence, have less access to formal financial services such as saving accounts and loans than men (Demirgüç-Kunt, Klapper, and Singer, 2013). They are consequently found to rely mainly on informal mechanisms (ROSCAs, money-lenders ...). Without a bank account, it is more difficult to build up savings and/or receive public benefits or remittances from family members living abroad (Demirgüç-Kunt et al. 2013). Dupas and Robinson (2013a) provide robust evidence that shows how women are more in need of formal saving devices than men. In a randomized field experiment in Kenya, they find that increasing access to basic savings bank account which does not pay interest, increases women savings while men's saving behavior is not impacted. This is why one may conjecture that women adoption of mobile money may have a comparatively greater impact on their saving behavior than men. Our investigation thus allows determining whether mobile money has the potential to cut back gender inequalities.

Finally, financial literacy or financial knowledge is yet to receive enough attention although there has been growing attention in the recent past. Recent research shows that across developed and developing countries the level of financial literacy remains very low (Karlan, Ratan and Zinman, 2014; Lusardi and Mitchell, 2014). Unsurprisingly, the unbanked population has relatively low level of education. Hence, it is difficult for them to understand various financial services that are available to them. This should partly explain their preference to use informal saving methods. Mobile money being affordable and easy to use, we can expect less educated people to adopt it for their saving purposes.

To sum up, we consider that if mobile money can significantly allow individuals to enhance their saving behavior, our research framework suggests the following questions: 
(i) Does the use of mobile money increase the capacity of individuals to save, particularly for unpredictable events such as health emergencies?

(ii) To the extent that mobile money is affordable, easy to use and available anywhere throughout the country, do disadvantaged groups such as individuals with low and irregular incomes, rural, female and less educated individuals benefit from the use of mobile money to increase their savings?

\section{Survey design and data collection}

We answer these questions by using individual-level data on the usage of mobile money combining with socio-demographics information collected through a survey we designed and conducted in Burkina Faso in 2014. The lack of official administrative data on actual uses of mobile money, saving behavior, health expenditures and several other microeconomic data especially at regional level constraints us to rely on hand-collected information even if we acknowledge that self-reported data may entail biases and limit the generality of the findings. Prior to a detailed examination of the characteristics about the location and population considered in our survey, it is worth providing an overview of the state of existing financial services in Burkina Faso.

\subsection{Background on mobile money and access to financial services in Burkina Faso}

Burkina Faso is a low-income country with a GDP per capita estimated at just 761 USD and about $47 \%$ of its population live under the national poverty line as of 2013 (World Bank, 2015). The country's financial system is still in its infancy even in comparison to other African lowincome countries ${ }^{9}$. There are about $13 \%$ of the population that have an account at a formal financial institution (bank account, post office, credit union and microfinance institutions); in contrast, this rate is around 35\% in Ghana, 55\% in Kenya and 69\% in South Africa as of 2011 (Global Financial Inclusion Database, 2015). The access to a bank account remains limited in the country and the

\footnotetext{
${ }^{9}$ We provide in Appendix Table A.7 statistics on access to financial services for Burkina Faso, Sub-Saharan Africa and Low-income countries.
} 
central bank (BCEAO) ${ }^{10}$ estimates the bankarization rate at about 4.6\% (BCEAO, 2011). In Burkina Faso, among individuals living in urban area, about 35\% have a formal financial account, while in rural area only 12\% have formal financial account (Global Financial Inclusion Database, 2015). This disparity in the access to formal finance is not confined to the location, approximately $12 \%$ of female have an account at formal financial institution compared to $15 \%$ of male.

Over the course of the past decade, cell (or mobile) phone coverage and adoption in Burkina Faso have increased substantially. While about $0.20 \%$ of the population had access to mobile phone in 2000 , the number of subscribers has increased to over $47 \%$ in 2011 , and continued to rise dramatically in the past few years to reach 60\% in 2012 and 65\% in 2013 (Group Special Mobile Association intelligence, 2015). In addition to basic services of mobile phones (calls, SMS), other services have been introduced over the past two years, namely, mobile financial services or mobile money. In the country, there are three mobile operators Airtel, Telmob and Telecel, but only the first two offer mobile money services which were launched respectively in 2012 (Airtel Money) and 2013 (MobiCash).

Since the launch of mobile money, the number of registered users has continuously increased and has been multiplied by seventeen between 2011 and $2014^{11}$ (Financial Access Survey, IMF, 2015). Ignoring multiple accounts held by individuals into each mobile money providers, this implies that about $5 \%$ of the adult population had gained access to mobile money in two years. Subscription to mobile money service is free of charge but requires an initial account balance of 500 FCFA (around \$1 US). The network of agents plays a key role in the adoption and usage of mobile money by making the conversion from cash to e-money and vice versa, more accessible and efficient for customers. In this regard, the number of mobile money agents has increased substantially from 483 in 2012 to 3,688 in May 2014 (Financial Access Survey, IMF, 2015). At any mobile money agent, depositing funds is free of charge whereas withdrawals are charged according to the amount. No interest is earned on account balances and mobile money providers do not make loans. Regarding money transfers, there is a fee ${ }^{12}$ per SMS transfer

\footnotetext{
${ }^{10}$ BCEAO: Banque Centrale des Etats de l'Afrique de l'Ouest. It is the Central Bank of the eight countries including Burkina Faso, of West Africa Economic and Monetary Union (WAEMU).

${ }^{11}$ The number of registered users grow from 70509 in 2011, 134583 in 2012, 828727 in 2013 to reach 1242476 in 2014 (Financial Access Survey, IMF, 2015).

${ }^{12}$ In our case study, the pricing schedule used by mobile money providers is a combination of a tiered/banded pricing and percentage based pricing (Garg, 2011). For more details, see the Appendix A.6.
} 
according to the mobile money provider. Withdrawal and transfer fees are deducted from user's accounts and details given in the appendix A.6 indicate that fees increase with the amount and are highly penalizing for small amounts. Hence, this creates an incentive for small amounts owners to keep it in their mobile money account in line with the soft commitment hypothesis at the core of this paper.

\subsection{Survey location and survey population}

In May 2014, we undertook a survey of 500 randomly selected people across one region of Burkina Faso. The country has 13 regions divided into many rural and urban municipalities. Due to budgetary constraints that did not allow us to extend the survey throughout the entire territory, only the central region was considered for the sample frame. This region counts about $13 \%$ of Burkina's population and is divided into one urban municipality with 12 districts and six rural municipalities with 172 districts. It is the most populated region and where the supply of formal financial institutions and to some extent the supply of mobile money institutions ${ }^{13}$ are relatively concentrated.

The survey location is determined on the basis of the following criteria: the first is the existence of at least one formal financial institution into retained municipalities -which we check through the national institute of statistics and demography (INSD) of Burkina Faso report on financial institutions ${ }^{14}$. The second criterion is the availability of mobile phone services that we assess through the availability of mobile operator signal. As stated above, the area covered by the sample frame is the central region and consists of one urban municipality, "Ouagadougou", and six rural municipalities among which only four have at least one formal financial institution. We then randomly select among the four, one municipality that is "Saaba" 15 . We finally randomly choose two districts for each municipality, i.e. two urban districts in Ouagadougou and two rural districts in Saaba.

\footnotetext{
13 The central region is the second after the western region where mobile money agents are concentrated $(29 \%$ for central region and $45 \%$ for western region).

${ }^{14}$ Note that among the two districts of the rural municipality considered in our study, there is one district where formal financial institutions are inexistent.

${ }^{15}$ In the rural municipality, Saaba, only two formal financial institutions one microfinance and one credit union institutions are present.
} 
To form our target population, we interview 125 individuals in each district by following an $\mathrm{n}$-th individual starting from the center of the district along the main directions of walk in the district. The individuals interviewed in each district have to live in the concerned district to avoid double interview. We decided to have a balanced sample of users and non-users of mobile money because, as emphasized above, our aim is to capture the impact of mobile money on saving behavior. Thus, individuals are interviewed until we obtain half of the sample to be users of mobile money irrespective of the municipalities. However, there is no restriction regarding individuallevel characteristics (gender, location, education level, level and types of incomes) in the sample.

A paper-based questionnaire was distributed to a total of 500 participants with 500 FCFA (about \$1 US) unit of call time incentive. The questionnaire combined qualitative and quantitative questions to elicit in-depth information about users and non-users of mobile money including individuals' socio-demographic characteristics. All research variables were measured using multiple-item scales and based on previous studies (Demirguc-kunt and Klapper, 2012; International Finance Corporation, 2011) with some changes to tailor them to our context. Most of the items were coded on dichotomous responses and on 5-point Likert scale. Our respondents were interviewed from 20 May to 28 June 2014. Participants who use the mobile money through their own cell phone or another cell phone were classified as users while participants who did not use the mobile money were classified as non-users. At the end of the survey, our sample consisted of $405^{16}$ respondents with $50.5 \%$ of mobile money users and $49.5 \%$ of non-users.

\subsection{Data and summary statistics}

Descriptive statistics (Table 1) show that, in our sample, most individuals saved regardless of their income levels. The share of individuals that reported saved is $92 \% ; 89 \%$ of which saved for health emergencies while 54\% saved to develop an activity. Regarding the gender, our sample is made of $51 \%$ of men and $49 \%$ of women. About $48 \%$ reported being married and the mean of age is about 31 years while $52 \%$ reported having at least one person in charge, and more than half of all individuals had at least secondary education level (more than six years of school). For the employment status, about $81 \%$ reported having a paid activity, while $16 \%$ were unemployed. More

\footnotetext{
${ }^{16}$ We ended up with a final sample of 405 respondents due to mistakes made during the process by some interviewers and respondents alike.
} 
than half of all individuals have a monthly income ranging from 10,000 to 50,000 FCFA (around $\$ 20$ to $\$ 100$ US), and about $48 \%$ of all individuals had irregular income.

Considering the two sub-samples of mobile money users and non-users it appears that mobile money users are more inclined to save for unpredictable events than non-users, while it is the opposite concerning saving for predictable purposes. We also notice that while mobile money users have more access to bank and credit union accounts than non-users, around $51 \%$ of non-users of mobile money use informal saving mechanisms compared to $38 \%$ for users of mobile money. Looking at the individual-level characteristics, the two groups reflect similar structures expect for marital situation with about $55 \%$ of mobile money users reported being married compared to $42 \%$ of non-users. Similarly, around 59\% of mobile money users are located in rural areas compared to $45 \%$ of non-users. Reports also show that around $44 \%$ of mobile money users have a monthly income ranging from 10,000 to 50,000 FCFA compared to 54\% of mobile money non-users.

In our data, $99 \%{ }^{17}$ of the sample use a mobile phone. Regarding the frequency of use of the 204 mobile money users interviewed during the survey, 53\% report using occasionally mobile money services. Majority of the mobile money users indicate to use the service to make person-toperson remittances: $79 \%$ receive transfers and $66 \%$ send transfers. Buying airtime stands at $71 \%$ of users, and a small share uses it to pay bills (about 1\%) and services (about 2\%). 90\% of mobile money users report to have saved during the past 12 months and among those, $35 \%$ saved using mobile money. Breaking down the responses according to the purpose of saving, we find that $85 \%$ of users report having saved to cope with health emergencies and $45 \%$ to develop an activity.

\footnotetext{
17 This rate of mobile phone usage in our sample is higher than the average rate of mobile phone subscription in Burkina Faso which stands at $65 \%$ as of 2013 and may raise questions about the generality of our findings. Therefore, we consider an alternative data survey collected at the country level provided by the Global Findex (2015) and find results that support our conclusions. Results are reported in Appendix Table A.5.2.
} 
Table 1. Data sample characteristics.

\begin{tabular}{|c|c|c|c|c|c|}
\hline & Full sample & $\begin{array}{r}\begin{array}{r}\text { Users of } \\
\text { mobile } \\
\text { money }\end{array}\end{array}$ & $\begin{array}{r}\begin{array}{r}\text { Non-users of } \\
\text { mobile } \\
\text { money }\end{array}\end{array}$ & $\begin{array}{r}\text { Individuals } \\
\text { that report } \\
\text { saved }\end{array}$ & $\begin{array}{r}\text { Individuals } \\
\text { that report not } \\
\text { saved }\end{array}$ \\
\hline \multicolumn{6}{|l|}{ Saving behavior } \\
\hline$\overline{\text { Save }}$ & $92 \%$ & $90 \%$ & $93 \%$ & - & - \\
\hline Save using mobile money account & $18 \%$ & $35 \%$ & - & $19 \%$ & - \\
\hline Save for health emergencies & $82 \%$ & $85 \%$ & $79 \%$ & $89 \%$ & - \\
\hline Save to develop an activity & $49 \%$ & $45 \%$ & $54 \%$ & $54 \%$ & - \\
\hline Usage of saving instruments & & & & & - \\
\hline$\overline{\text { Bank account }}$ & $39 \%$ & $45 \%$ & $34 \%$ & $43 \%$ & - \\
\hline Credit union account & $47 \%$ & $49 \%$ & $45 \%$ & $51 \%$ & - \\
\hline Mobile money account & $18 \%$ & $35 \%$ & - & $19 \%$ & - \\
\hline Informal mechanisms & $45 \%$ & $38 \%$ & $51 \%$ & $49 \%$ & - \\
\hline \multicolumn{6}{|l|}{ Gender } \\
\hline Female & $49 \%$ & $49 \%$ & $48 \%$ & $49 \%$ & $52 \%$ \\
\hline Male & $51 \%$ & $51 \%$ & $53 \%$ & $51 \%$ & $48 \%$ \\
\hline \multicolumn{6}{|l|}{ Marital status } \\
\hline Married & $48 \%$ & $55 \%$ & $42 \%$ & $51 \%$ & $26 \%$ \\
\hline At least one person in charge & $52 \%$ & $52 \%$ & $47 \%$ & $52 \%$ & $55 \%$ \\
\hline \multicolumn{6}{|l|}{$\underline{\text { Age }}$} \\
\hline$\overline{<30}$ & $51 \%$ & $49 \%$ & $53 \%$ & $48 \%$ & $74 \%$ \\
\hline$>=30$ & $49 \%$ & $51 \%$ & $47 \%$ & $51 \%$ & $26 \%$ \\
\hline \multicolumn{6}{|l|}{ Location } \\
\hline Rural & $52 \%$ & $59 \%$ & $45 \%$ & $48 \%$ & $55 \%$ \\
\hline Urban & $48 \%$ & $41 \%$ & $55 \%$ & $52 \%$ & $45 \%$ \\
\hline \multicolumn{6}{|l|}{ Education level } \\
\hline Less than secondary education level & $42 \%$ & $36 \%$ & $47 \%$ & $43 \%$ & $32 \%$ \\
\hline At least secondary education level & $58 \%$ & $64 \%$ & $53 \%$ & $57 \%$ & $68 \%$ \\
\hline \multicolumn{6}{|l|}{ Occupation / employment status } \\
\hline Paid activity & $81 \%$ & $77 \%$ & $85 \%$ & $84 \%$ & $55 \%$ \\
\hline Unpaid activity (include students) & $16 \%$ & $18 \%$ & $13 \%$ & $13 \%$ & $42 \%$ \\
\hline \multicolumn{6}{|l|}{ Income level and type } \\
\hline Income ranging from 10000 to $50000 \mathrm{FCFA}$ & $60 \%$ & $44 \%$ & $54 \%$ & $46 \%$ & $74 \%$ \\
\hline Income more than 50000 FCFA & $40 \%$ & $56 \%$ & $46 \%$ & $54 \%$ & $26 \%$ \\
\hline Irregular income & $48 \%$ & $50 \%$ & $46 \%$ & $46 \%$ & $65 \%$ \\
\hline Regular income & $52 \%$ & $50 \%$ & $54 \%$ & $53 \%$ & $35 \%$ \\
\hline \multicolumn{6}{|l|}{ Usage of mobile phone (or mobile technology) } \\
\hline Mobile phone user & $99 \%$ & $99 \%$ & $100 \%$ & $99 \%$ & $100 \%$ \\
\hline \multicolumn{6}{|l|}{ Frequency of the use of mobile money } \\
\hline Occasionally & & $53 \%$ & & & \\
\hline Once a month & & $6 \%$ & & & \\
\hline Several times a month & & $34 \%$ & & & \\
\hline Once a week & & $2 \%$ & & & \\
\hline Several times a week & & $10 \%$ & & & \\
\hline \multicolumn{6}{|l|}{ Usage of mobile money services } \\
\hline Send money transfers & & $66 \%$ & & & \\
\hline Receive money transfers & & $79 \%$ & & & \\
\hline Buy airtimes & & $71 \%$ & & & \\
\hline Pay bills & & $1 \%$ & & & \\
\hline Purchase goods and services & & $2 \%$ & & & \\
\hline
\end{tabular}

Source: Author's analysis of the survey data collected in May 2014 in Burkina Faso. Throughout, F CFA (Franc of the African Financial Community) refers to the local currency. The exchange rate during the survey period was about $500 \mathrm{~F} \mathrm{CFA}=\$ 1 \mathrm{US}$. 


\section{Model specification and endogeneity issue}

In this section, we describe our empirical specifications used to test the relationship between the use of mobile money and saving choices, as well as the potential heterogeneity effects of mobile money depending on individuals' characteristics. We also discuss the endogeneity issue related to the use of mobile money and how we propose to deal with it.

\section{a) Model specification}

We use a logistic model to examine the impact of mobile money usage on individual saving patterns considering the following specification ${ }^{18}$ :

$$
\operatorname{PROB}\left\{y_{i}=1\right\}=\Phi\left(\alpha_{1}+\alpha_{2} \text { MMuser }+\alpha_{3} I C_{i}\right)
$$

where $\Phi$ is the cumulative distribution function of logistic distribution.

In the equation (1), $y_{i}$ is our dependent variable that characterizes individual saving behavior. It is a binary variable that alternatively stands for: save for unpredictable events, save for anticipated objectives, save for health emergencies and save to develop an activity ${ }^{19}$. These latter two dependent variables are measured through the following questions: "During the past 12 months, did you save some of your money to develop an activity?"; "to cope with health emergencies?" Other propositions were offered as well to the respondents but we retain saving for health emergencies and saving to develop an activity ${ }^{20}$. Thus, save for health emergencies

\section{Table 2. Definitions of the variables.}

\footnotetext{
${ }^{18}$ In our logit estimations we use robust standard errors to take into account undetected (or possible) specification errors regarding the right hand side variables (Freedman, 2006) but all our main conclusions remain unchanged when using standard errors (i.e. by assuming homoskedacity) (results are available upon request).

${ }^{19}$ Our first two alternative dependent variables: saving for unpredictable events and saving for anticipated shocks were constructed by aggregating the responses obtained about the objectives of individual's savings (Table 2). In our questionnaire we ask the following question "During the past 12 months, did you save some of your money for education spending?"; "to develop an activity?"; "to repay a loan?"; "for a potential decrease in income?"; "to cope with health emergencies?"; "for a ceremony (wedding, funeral)?" However, only saving for health emergencies and saving to develop an activity were mainly retained. This is consistent with previous studies on the importance of commitment devices on saving behavior which consider health emergencies (Dupas and Robinson, 2013b; Mbarathi and Diga, 2014) or savings for enterprise development (Ashraf et al., 2010; Dupas and Robinson, 2013a). The relatively low response rate on the other objectives of savings also motivated us to focus on the two motives.

${ }^{20}$ See footnote 18 about the rationale of this choice.
} 


\begin{tabular}{|c|c|c|c|}
\hline Variable & Definition & Obs. & Mean \\
\hline $\begin{array}{l}\text { Mobile money user } \\
\text { (MM user) }\end{array}$ & $\begin{array}{l}\text { Reply to the question: Do you use mobile money services? Encoded as } \\
\qquad y e s=1, \text { no }=0\end{array}$ & 405 & 0.5 \\
\hline $\begin{array}{l}\text { Save for } \\
\text { unpredictable events }\end{array}$ & $\begin{array}{c}\text { Indicate when respondent's saving was for unpredictable purposes, } \\
\text { encoded as (save for health emergencies, and/or save for an eventual } \\
\text { decrease in income }=1 \text {, others }=0 \text { ) }\end{array}$ & 374 & 0.93 \\
\hline $\begin{array}{l}\text { Save for health } \\
\text { emergencies }\end{array}$ & $\begin{array}{l}\text { Reply to the question: During the past } 12 \text { months, did you save to cope } \\
\text { with health emergencies? Encoded as yes }=1, \text { no }=0\end{array}$ & 374 & 0.89 \\
\hline $\begin{array}{l}\text { Save for predictable } \\
\text { events }\end{array}$ & $\begin{array}{l}\text { Indicate when respondent's saving was for predictable events, encoded } \\
\text { as (save for education, save to develop an activity, save to repay a loan } \\
\text { and/or save for a ceremony such as wedding or funeral }=1 \text {, others }=0 \text { ) }\end{array}$ & 375 & 0.70 \\
\hline $\begin{array}{l}\text { Save to develop an } \\
\text { activity }\end{array}$ & $\begin{array}{l}\text { Reply to the question: During the past } 12 \text { months, did you save to } \\
\text { develop an activity? Encoded as yes }=1, \text { no }=0\end{array}$ & 372 & 0.53 \\
\hline \multicolumn{4}{|c|}{ Individuals' characteristics } \\
\hline Age & Indicate the age of respondent & 404 & 30.55 \\
\hline Male & Indicate the gender of respondent, Encoded as Male $=1$, Female $=0$ & 405 & 0.51 \\
\hline Married & $\begin{array}{l}\text { Indicate the marital situation of respondent, Encoded as Married }=1 \text {, } \\
\qquad \text { Single }=0\end{array}$ & 405 & 0.48 \\
\hline $\begin{array}{l}\text { At least one person } \\
\text { in charge }\end{array}$ & $\begin{array}{l}\text { Indicate if the respondent has or not dependent, Encoded as Having } \\
\text { dependent }=1 \text {, otherwise }=0\end{array}$ & 401 & 0.53 \\
\hline Education & $\begin{array}{l}\text { Indicate the education level of respondent, Encoded as Illiterate }=1 \text {, } \\
\text { Primary }=2, \text { Secondary }=3 \text {, University }=4\end{array}$ & 402 & 2.67 \\
\hline Rural & Indicate the location of respondent, Encoded as Rural $=1$, Urban $=0$ & 405 & 0.52 \\
\hline Occupation & $\begin{array}{l}\text { Indicate the employment status of respondent, Encoded as (Employed, } \\
\text { Entrepreneur, Merchant, Farmer })=1 \text {, (Unemployed, Student })=0\end{array}$ & 391 & 0.84 \\
\hline Income & $\begin{array}{c}\text { Indicate the monthly income of respondent, encoded as Less than } \\
10,000 \mathrm{FCFA}=1,10,000 \text { to } 50,000 \mathrm{FCFA}=2,50,000 \text { to } 150,000 \\
\text { FCFA }=3,150,000 \text { to } 300,000 \mathrm{FCFA}=4,300,000 \text { to } 500,000 \mathrm{FCFA}= \\
5 \text {, More than } 500,000 \mathrm{FCFA}=6\end{array}$ & 405 & 2.61 \\
\hline Irregular income & $\begin{array}{l}\text { Indicate the type of income of respondent, encoded as Irregular }=1 \text {, } \\
\qquad \text { Regular }=0\end{array}$ & 403 & 0.48 \\
\hline
\end{tabular}

Note: Throughout, F CFA (Franc of the African Financial Community) refers to the local currency. The exchange rate during the survey period was about $500 \mathrm{~F} \mathrm{CFA}=\$ 1 \mathrm{US}$. 
takes the value one if respondent indicates save for health emergencies, and zero otherwise. Similarly, save to develop an activity equals to one if respondent saves to develop an activity, and zero otherwise $^{21}$. MMuser ${ }_{i}$ is the independent variable of interest that stands for the use of mobile money. It is a dummy variable equal to one if the individual reports using mobile money and zero otherwise. $I C_{i}$ is a vector for controls (age, gender, marital situation, at least one person in charge, education level, location, occupation or employment status, level and type of income). We present in Table 2 the variables' definitions along with some summary statistics.

If both users and non-users of mobile money do not differ in terms of their propensity to save, the coefficient $\alpha_{2}$ should not be significantly different from zero. If users of mobile money are more capable to save than non-users, then $\alpha_{2}$ should be positive and statistically different from zero.

Mobile money usage could have different impact on saving for health emergencies and to develop an activity when considering individuals' characteristics. Therefore, we slightly modify our specification (1) and include interaction terms as follows:

$$
\operatorname{PROB}\left(y_{i}=1\right)=\Phi\left(\beta_{1}+\beta_{2} \text { MMuser }_{i}+\beta_{3} D_{i}+\beta_{4} \text { MMuser }_{i} \times D_{i}+\beta_{5} D_{i} \times I C_{i}^{\prime}+\beta_{6} I C_{i}^{\prime}\right)
$$

Where, $D_{i}$ is a dummy variable that stands alternatively for individuals' characteristics that we use to assess the impact of mobile money use on saving behavior for low vs. high income, irregular vs. regular income, rural vs. urban, female vs. male, and less vs. highly educated individuals. Accordingly, it takes the value 1 for disadvantaged individuals, i.e. low level of income, irregular income, rural, female and less educated individuals, and takes the value 0 respectively for high level of income, regular income, urban, male and highly educated individuals. $I C_{i}^{\prime}$ is our vector of controls excluding the individuals' characteristics considered for the dummy variable $D_{i}$.

The coefficients of interest are both $\beta_{2}$ and the total effect given by the sum of $\beta_{2}+\beta_{4}$. For instance, if $\beta_{2}$ is positive and significantly different from zero, then the use of mobile money increases the likelihood of advantaged individuals to save than those who do not use mobile money.

\footnotetext{
${ }^{21}$ For precise definitions of how we construct these dummies, see Table 2.
} 
Similarly, if disadvantaged individuals who use mobile money have more likelihood to save than those who do not use mobile money then, $\beta_{2}+\beta_{4}$ should be positive and significantly different from zero.

\section{b) Endogeneity issue}

To identify the causal effect in our equation of mobile money on saving choices, we must assume that the variable "mobile money user" is exogenous and uncorrelated with the error term. However, this may not be the case because, as stressed above, access to formal financial services is very limited in Burkina Faso. This lack of access may lead individuals to rely on informal mechanisms to manage their finances. Although mobile money was initially launched for money transfers, individuals may use it to save due to its convenience (safety and ease of access) even if it does not pay any interest (Demombynes and Thegeya, 2012; Dermish et al. 2012).

The endogeneity problem suspected here stems from the simultaneous determination of the use of mobile money and saving choices of individuals ${ }^{22}$. Thus, to tackle the potential endogeneity issue we perform an instrumental variable (IV) linear probability model (LPM) using 2SLS estimator (Angrist and Pischke, 2008). Given that we have one potential endogenous variable, the use of mobile money, we need at least one instrumental variable. Therefore, we use one excluded instrument, the distance to the nearest mobile money proposed by Jack and Suri (2014). We assess this distance by using the answer to the following question: "What distance did you travel to reach a mobile money agent?" The responses are encoded on a 5-point Likert scale, 1 (less than $1 \mathrm{~km}), 2$ (1 to $2 \mathrm{~km}), 3(2$ to $5 \mathrm{~km}), 4(5$ to $10 \mathrm{~km}$ ) and 5 (more than $10 \mathrm{~km}$ ). The underlying hypothesis of this instrument is that access to mobile money agents is required for cash in/out functions that allows for an effective use of mobile money. However, the distance to the nearest mobile money agent may not be correlated with individuals' characteristics that could affect saving for specific purposes. This is plausible in our case because in Burkina Faso, mobile money agents are mainly made of retail outlets who decide to start mobile money business on top of their existing business

\footnotetext{
${ }^{22}$ Additional likely sources of bias may be due to the choice of areas covered by our survey. We discuss in Appendix A.5 about the external validity of our study and use nationally representative data from Global Financial Inclusion Database (World Bank, 2015) that overcome the geographical selection problem to check the consistency of our estimations. Also Batista and Vicente (2016), who randomize the introduction of mobile money across geographical locations of rural Mozambique, find results that support our findings.
} 
in order to diversify their services and incomes. Importantly, these retail agents are usually shopkeepers or small businessmen who sell mobile accessories and they are often located in remote areas near the poor households. Although mobile money operators (and partner bank branches) have their own mobile money agents who are more likely to be located near places where there are income generating activities, the cost of installation is such that mobile money providers may favor the retail outlets. In all cases, given that the network of mobile operators covers around $80 \%$ of the country (GSMA, 2015), mobile money services are offered in low income areas as well. This is further supported by Munyegera and Matsumoto (2016) who show that the decision of mobile money providers for licensing an agent is related to the prescribed requirements regardless of the geographical and socio-economic characteristics of the agent's location ${ }^{23}$.

We expect the coefficient of this variable distance to have a negative sign as the further individuals are from mobile money agents, the harder it will be to access mobile money services, and this may reduce adoption/usage of mobile money. In Tables 3 to 7 we do not present first-stage regressions (to save space) but we show F statistic on the instruments for both MM user and its interactions and the Kleibergen-Paap F statistic along with the corresponding Stock-Yogo critical values at $10 \%$ for the relevance of the instrument.

\section{Results}

Table 3 presents our results about the impact of using mobile money on the propensity to save for unpredictable events, to save for health emergencies, to save for predictable events and, to save in order to develop an activity (columns 1 to 4 ). We report in columns 5 to 8 the results obtained by estimating the IV linear probability model (LPM) using 2SLS estimator ${ }^{24}$. However, the null hypothesis of exogeneity ${ }^{25}$ related to the use of mobile money is not rejected across all our estimations. In the columns 1 and 2, we find that the coefficient of the variable of interest $(M M$

\footnotetext{
${ }^{23}$ We check whether the distance to the nearest mobile money agent is correlated with individuals' characteristics in our analysis. We find little evidence that distance to agent is associated with individuals' characteristics (results are available upon request). Jack and Suri (2014) also show that the rollout of agents is uncorrelated with wealth among other factors.

${ }^{24}$ Results from the IV linear probability model (LMP) using 2SLS estimator are obtained using the ivreg2 command from Stata.

${ }^{25}$ We use the endogeneity test proposed by Baum, Schaffer and Stillman (2007) and its statistic is numerically equal to a Hausman test statistic under conditional homoskedasticity.
} 
user) is positive and significantly different from zero. But in columns 3 and 4 this coefficient is not statistically significant. Thus, the propensity to save for unpredictable purposes and for health emergencies is respectively about $3^{26}$ and 2.5 times higher for users of mobile money than nonusers. This effect is by contrast not significant on individuals' propensity to build up savings for predictable events and savings to develop an activity. Thus, these results indicate that mobile money usage helps to build savings for health emergencies while there is no difference between users and non-users in their saving behavior for long term objectives such as to develop their activity. As highlighted in our research framework (section 2.1), these findings may support therefore the fact that as mobile money increases access to cash, individuals would use it for unanticipated events such as health emergencies. By contrast, they would prefer other means, perhaps relatively less liquid devices, to save for predictable events (or long term objectives) ${ }^{27}$. This is in line with Mbarathi and Diga (2014) and Morawczynski and Pickens (2009) who argue that people may use mobile money account for emergencies while for long-term savings, they would prefer tools that limit access to cash (such as bank accounts due to long distance or participation into a ROSCA). Our findings are also consistent with those of Batista and Vicente (2016) who randomize the introduction of mobile money across geographical locations in rural Mozambique and find that mobile money is associated with less vulnerability to shocks and with less agricultural and business investment (which could be associated with savings for predictable purposes).

\footnotetext{
${ }^{26}$ The coefficients reported in all our tables are the log odds of the use of mobile money on saving patterns. To obtain the odds ratio, we simply compute the exponential of log odds.

${ }^{27}$ In the next section, we discuss in detail the potential mechanisms or pathways behind these findings.
} 
Table 3. Saving choices and mobile money ${ }^{28}$.

\begin{tabular}{|c|c|c|c|c|c|c|c|c|}
\hline & \multicolumn{4}{|c|}{ Logit regressions } & \multicolumn{4}{|c|}{ IV regressions } \\
\hline & $\begin{array}{l}\text { Save for } \\
\text { unpredictable } \\
\text { purposes }\end{array}$ & $\begin{array}{l}\text { Save for } \\
\text { health } \\
\text { emergencies }\end{array}$ & $\begin{array}{l}\text { Save for } \\
\text { predictable } \\
\text { events }\end{array}$ & $\begin{array}{c}\text { Save to } \\
\text { develop } \\
\text { an activity }\end{array}$ & $\begin{array}{c}\text { Save for } \\
\text { unpredictable } \\
\text { events }\end{array}$ & $\begin{array}{l}\text { Save for } \\
\text { health } \\
\text { emergencies }\end{array}$ & $\begin{array}{l}\text { Save for } \\
\text { predictable } \\
\text { events }\end{array}$ & $\begin{array}{c}\text { Save to } \\
\text { develop } \\
\text { an activity }\end{array}$ \\
\hline & $(1)$ & $(2)$ & (3) & $(4)$ & $(5)$ & (6) & $(7)$ & $(8)$ \\
\hline \multirow[t]{2}{*}{ MM user } & $1.091 * *$ & $0.922 * *$ & -0.512 & -0.142 & $0.055^{*}$ & $0.076 * *$ & $-0.107 * *$ & -0.022 \\
\hline & $(0.527)$ & $(0.379)$ & $(0.324)$ & $(0.295)$ & $(0.031)$ & $(0.038)$ & $(0.046)$ & $(0.047)$ \\
\hline \multirow[t]{2}{*}{ Age } & 0.206 & 0.070 & $0.354 * *$ & $0.438 * *$ & 0.014 & 0.013 & $0.070 * * *$ & $0.063 * * *$ \\
\hline & $(0.286)$ & $(0.261)$ & $(0.160)$ & $(0.181)$ & $(0.021)$ & $(0.024)$ & $(0.021)$ & $(0.024)$ \\
\hline \multirow[t]{2}{*}{ Age squared } & -0.002 & -0.000 & -0.004 & $-0.006 * *$ & -0.000 & -0.000 & $-0.001 * * *$ & $-0.001 * *$ \\
\hline & $(0.004)$ & $(0.004)$ & $(0.002)$ & $(0.003)$ & $(0.000)$ & $(0.000)$ & $(0.000)$ & $(0.000)$ \\
\hline \multirow[t]{2}{*}{ Married } & 0.196 & -0.084 & -0.449 & $-0.936 * * *$ & 0.018 & -0.013 & -0.050 & $-0.147 * * *$ \\
\hline & $(0.701)$ & $(0.550)$ & $(0.350)$ & $(0.356)$ & $(0.049)$ & $(0.055)$ & $(0.053)$ & $(0.054)$ \\
\hline \multirow[t]{2}{*}{ Rural } & 0.0605 & 0.143 & 0.219 & $-0.949 * * *$ & -0.002 & 0.014 & 0.040 & $-0.139 * * *$ \\
\hline & $(0.438)$ & $(0.400)$ & $(0.322)$ & $(0.359)$ & $(0.030)$ & $(0.039)$ & $(0.047)$ & $(0.048)$ \\
\hline \multirow[t]{2}{*}{ Male } & 0.179 & 0.006 & 0.308 & 0.254 & 0.005 & -0.005 & 0.045 & 0.008 \\
\hline & $(0.505)$ & $(0.386)$ & $(0.318)$ & $(0.329)$ & $(0.030)$ & $(0.037)$ & $(0.047)$ & $(0.048)$ \\
\hline \multirow[t]{2}{*}{ Occupation } & -0.262 & 0.896 & 0.528 & $2.842 * * *$ & -0.006 & 0.102 & $0.154^{*}$ & $0.253 * * *$ \\
\hline & $(0.998)$ & $(0.576)$ & $(0.542)$ & $(0.938)$ & $(0.044)$ & $(0.072)$ & $(0.088)$ & $(0.077)$ \\
\hline \multirow[t]{2}{*}{ Irregular income } & -0.471 & -0.113 & $1.544 * * *$ & $2.499 * * *$ & -0.029 & -0.006 & $0.242 * * *$ & $0.435 * * *$ \\
\hline & $(0.547)$ & $(0.451)$ & $(0.318)$ & $(0.376)$ & $(0.034)$ & $(0.042)$ & (0.049) & $(0.053)$ \\
\hline \multirow[t]{2}{*}{ Person in charge } & 0.291 & -0.036 & 0.0418 & -0.014 & 0.019 & -0.004 & 0.004 & 0.000 \\
\hline & $(0.411)$ & $(0.331)$ & $(0.291)$ & $(0.284)$ & $(0.026)$ & $(0.033)$ & $(0.041)$ & $(0.042)$ \\
\hline \multirow[t]{2}{*}{ Education } & $0.629 * * *$ & $0.382 *$ & -0.236 & $-0.610^{* * *}$ & $0.041 * *$ & $0.041 * *$ & -0.020 & $-0.107 * * *$ \\
\hline & $(0.232)$ & $(0.208)$ & $(0.197)$ & $(0.185)$ & $(0.016)$ & $(0.021)$ & $(0.027)$ & $(0.029)$ \\
\hline \multirow[t]{2}{*}{ Income } & -1.376 & -0.675 & -1.771 & -1.334 & -0.086 & -0.064 & -0.049 & -0.122 \\
\hline & $(1.325)$ & $(1.402)$ & (1.594) & $(1.222)$ & $(0.066)$ & $(0.116)$ & $(0.143)$ & $(0.164)$ \\
\hline \multirow[t]{2}{*}{ Income squared } & 0.141 & 0.100 & 0.477 & $0.346^{*}$ & 0.008 & 0.008 & 0.027 & $0.041^{*}$ \\
\hline & $(0.198)$ & $(0.223)$ & $(0.312)$ & $(0.198)$ & $(0.009)$ & $(0.017)$ & $(0.021)$ & $(0.025)$ \\
\hline \multirow[t]{2}{*}{ Constant } & -0.849 & -0.830 & $-5.009 *$ & $-7.576^{* *}$ & $0.667 * *$ & 0.465 & $-0.843 * *$ & -0.500 \\
\hline & $(4.020)$ & $(3.801)$ & $(2.961)$ & $(3.242)$ & $(0.308)$ & $(0.382)$ & $(0.364)$ & $(0.406)$ \\
\hline Observations & 352 & 352 & 353 & 350 & 352 & 352 & 353 & 350 \\
\hline Pseudo R2 / R2 & 0.120 & 0.075 & 0.285 & 0.359 & 0.060 & 0.054 & 0.310 & 0.403 \\
\hline $\begin{array}{l}\text { Wald } \chi^{2} \text { (H0: nullity of } \\
\text { coefficients) }\end{array}$ & $32.31 * * *$ & $23.08 * *$ & $40.96 * * *$ & $71.39 * * *$ & & & & \\
\hline $\begin{array}{l}\text { Likelihood ratio test } \chi^{2} \\
\text { (H0: nullity of coefficients) }\end{array}$ & $25.47^{* *}$ & $24.62 * *$ & $93.51 * * *$ & $204.46^{* * *}$ & & & & \\
\hline$\%$ correct prediction $(\mathrm{y}=1)$ & $77.91 \%$ & $52.26 \%$ & $75.96 \%$ & $85.79 \%$ & & & & \\
\hline$\%$ correct prediction $(\mathrm{y}=0)$ & $61.54 \%$ & $69.05 \%$ & $73.85 \%$ & $78.75 \%$ & & & & \\
\hline \multicolumn{5}{|c|}{ First stage F-stat on instrument for MM user } & $51.40 * * *$ & $51.40 * * *$ & $51.87 * * *$ & $50.79 * * *$ \\
\hline \multicolumn{5}{|c|}{$\begin{array}{l}\text { Kleibergen-Paap Wald rk F-stat (H0: } \\
\text { equation is weakly identified) }\end{array}$} & 51.40 & 51.40 & 51.87 & 50.79 \\
\hline \multicolumn{5}{|c|}{ Stock-Yogo critical values $(10 \%)$} & 16.38 & 16.38 & 16.38 & 16.38 \\
\hline \multicolumn{5}{|c|}{$\begin{array}{l}\text { Endogeneity test of MM user (H0: } \\
\text { Exogeneity) }\end{array}$} & 2.555 & 2.175 & 2.555 & 2.555 \\
\hline \multicolumn{5}{|c|}{$\begin{array}{l}\text { Exogeneity) } \\
\text { p-value }\end{array}$} & 0.110 & 0.140 & 0.110 & 0.110 \\
\hline \multicolumn{5}{|c|}{ Pagan-Hall t-test (H0: homoskedasticity) } & $24.248 * *$ & 17.939 & $31.895 * * *$ & $30.372 * * *$ \\
\hline \multicolumn{9}{|c|}{$\begin{array}{l}\text { Note: Dependent variables: save for unpredictable purposes, save for health emergencies, save for predictable events and save to develop an activity are all } \\
\text { lummies. Save for unpredictable purposes equal to } 1 \text { if respondents save for health emergencies and/or save for a potential decrease in income, and } 0 \text { otherwise. } \\
\text { Save for health emergencies takes the value } 1 \text { if respondents indicate to save for health emergencies, and } 0 \text { otherwise. Similarly, save for predictable events equal } \\
\text { o } 1 \text { if respondents save to develop an activity or, save for education or, save to repay a loan and/or save for a ceremony (such as wedding or funeral), and } 0 \\
\text { therwise. Save to develop an activity also takes the value } 1 \text { if respondents save to develop an activity, and o otherwise. The variable of interest, MM user is also } \\
\text { dummy that equal to } 1 \text { if respondents use mobile money, and } 0 \text { otherwise. The coefficients reported in the table are the log odds of the use of mobile money on } \\
\text { aving patterns. To obtain the odds ratio, we simply compute the exponential of log odds. Robust standard errors are in brackets. *** Significant at the } 1 \% \text { level, } \\
* * \text { Significant at the } 5 \% \text { level, * Significant at the } 10 \% \text { level. }\end{array}$} \\
\hline
\end{tabular}

${ }^{28}$ The correlation matrix is provided in the Appendix A.1. Married and age which are highly correlated $(0.61)$ were introduced alternately in the regression and we obtained similar results. 
Regarding our control variables, we find that only education matters when considering columns 1 and 2. Its positive and significant coefficient indicates that increasing the education level is positively and significantly correlated with the propensity to save for unpredictable purposes or for health emergencies.

Across the two remaining columns, particularly column 4, the reported results show that instead of mobile money usage, it is rather the socio-demographic characteristics that are significantly associated with individual saving behavior for long term objectives such as to develop an activity. Precisely, we find age, occupation and irregular income to be positively and significantly related to saving to develop an activity while married, rural and, counterintuitively, education are negatively and significantly correlated with saving to develop an activity. The negative and significant coefficient associated with age squared implies a hump-shape relationship between saving to develop an activity and age. This is consistent with the life-cycle hypothesis stressing that individuals spread their lifetime consumption over their lives by accumulating savings during earning years and maintaining consumption levels during retirement. Individuals' employment status (occupation) gives important information that may determine their saving behavior. Intuitively, individuals who have a paid activity are more inclined to save than unemployed people. The results show the coefficient associated with individuals' employment status positive and significant. This result implies as expected that individuals having a paid activity are more likely to save to develop an activity than those without a paid activity. Regarding the positive and significant coefficient associated with irregular income, it may reflect the behavior of individuals who care about stabilizing their incomes. This is consistent with the permanent-income hypothesis assuming that people attempt to maintain a fairly constant standard of living even though their incomes may vary considerably.

Turning to the control variables that are negatively and significantly associated with saving to develop an activity, marital situation (married) may reflect the "size effect" which emphasizes that a household of more than one individual would have less propensity to save to develop an activity than a single individual. Regarding geographical location (rural), compared to individuals living in urban area, those living in rural area have lower access to alternative means of saving for long term purposes as formal financial institutions 
Table 4. Saving choices and mobile money: Low, irregular vs. High, regular incomes.

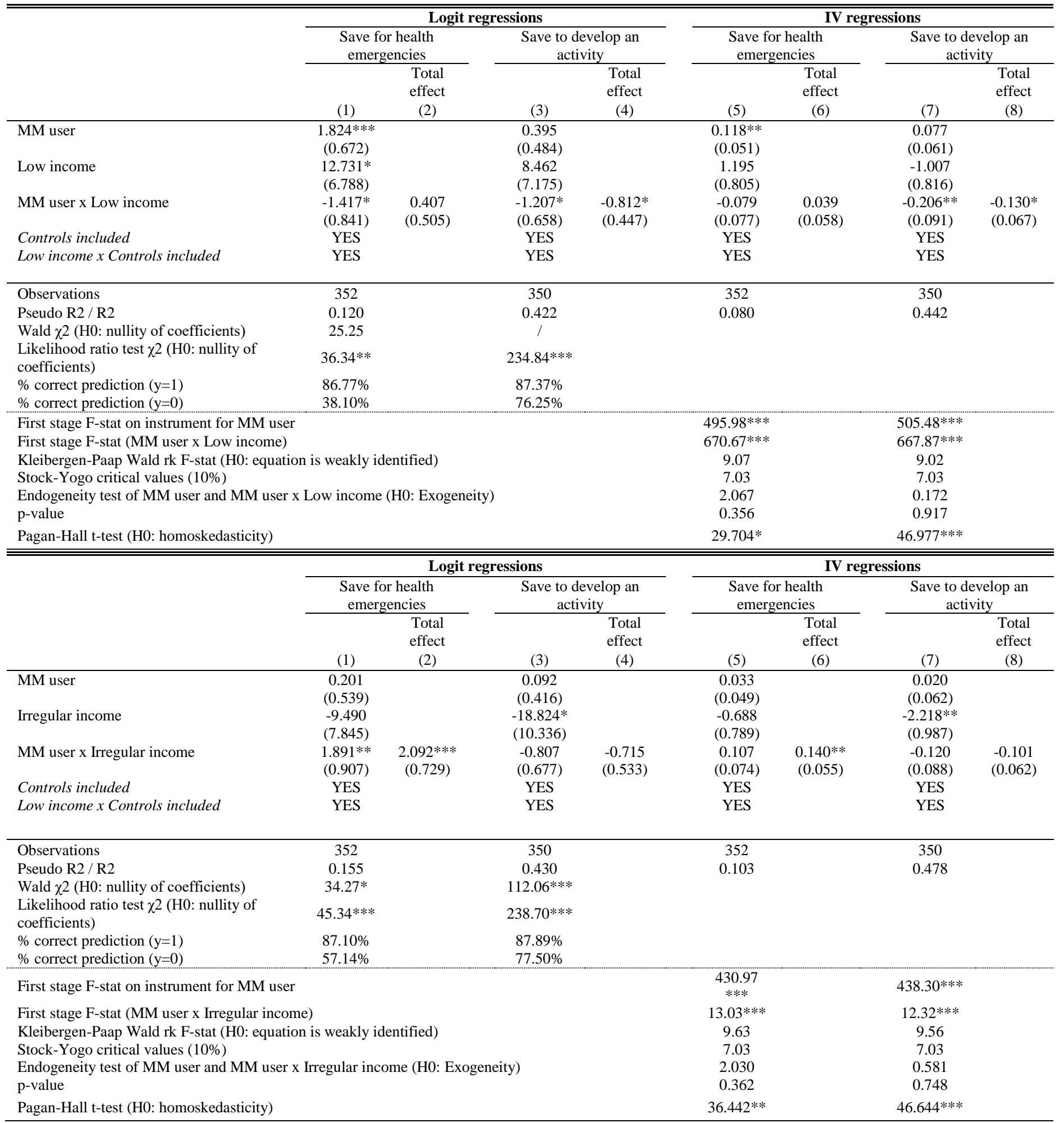

Note: Dependent variables: save for health emergencies and save to develop an activity. Save for health emergencies takes the value 1 if respondents indicate to save for health emergencies, and 0 otherwise. Save to develop an activity also takes the value 1 if respondents save to develop an activity, and o otherwise. The coefficients reported in the table are the log odds of the use of mobile money on saving patterns. To obtain the odds ratio, we simply compute the exponential of log odds. Robust standard errors are in brackets. Low income individuals are those with less than 50,000 F CFA (around \$100US) per month. Irregular income individuals are those who specify having irregular income by answering the following question: "Do you have regular or irregular income?" The responses are encoded as irregular income $=1$, and regular income $=0$. Controls included: age, age squared, married, rural, male, occupation, irregular income, at least one person in charge, education level, income level and income squared. According to the individual-level characteristics used we remove respectively controls income level and income squared, and irregular income. *** Significant at the $1 \%$ level, ** Significant at the 5\% level, * Significant at the $10 \%$ level. 
are mainly concentrated in urban area. As regards to our counterintuitive result which shows that education is negatively and significantly linked to the propensity to save in order to develop an activity, one explanation may be that in our sample highly educated individuals are likely to be those who are still attending university while less educated individuals are likely to be employed suggesting that they will comparatively have more inclination to save to develop their activity. Moreover, highly educated individuals may have better access to credit in formal financial institutions than less educated individuals as they may be more financially literate. They are hence more likely to understand the various financial services available to them and do not face difficulties to fill out loan applications.

Our discussion in the research framework (section 2.2) also stressed how the relationship between mobile money and saving behavior may depend on particular exogenous characteristics. Accordingly, in Table 4, we present our results obtained by distinguishing individuals on the basis of the level and the type of their incomes. Our assumption is that individuals with low or irregular incomes may find the innovation of mobile money convenient and hence rely more on it to save than people who benefit from high or regular incomes. Our reported results reject our hypothesis on low income but confirm that on irregular income. In fact, they show that for low income individuals, the use of mobile money has no effect on users' propensity to save for health emergencies and discloses a slight significant effect (at 10\%) but negative on user behavior to save for developing an activity. By contrast, as far as high income individuals are concerned, our results show a positive and highly significant coefficient of usage of mobile money on the propensity to save for health emergencies. These results may therefore suggest the existence of a "threshold income" effect beyond which the use of mobile money is positively and significantly associated with saving for health emergencies. Regarding the type of income, we find as expected that the coefficient associated with our variable of interest (MM user) is positive and significant only for individuals with irregular incomes indicating that the propensity to save for health emergencies is 8 times higher for mobile money users than for non-mobile money users.

We now consider our remaining set of characteristics that may influence how the usage of mobile money affects saving. Table 5 takes this into account and distinguishes individuals on the 
Table 5. Saving choices and mobile money: Low vs. High access to formal financial instruments.

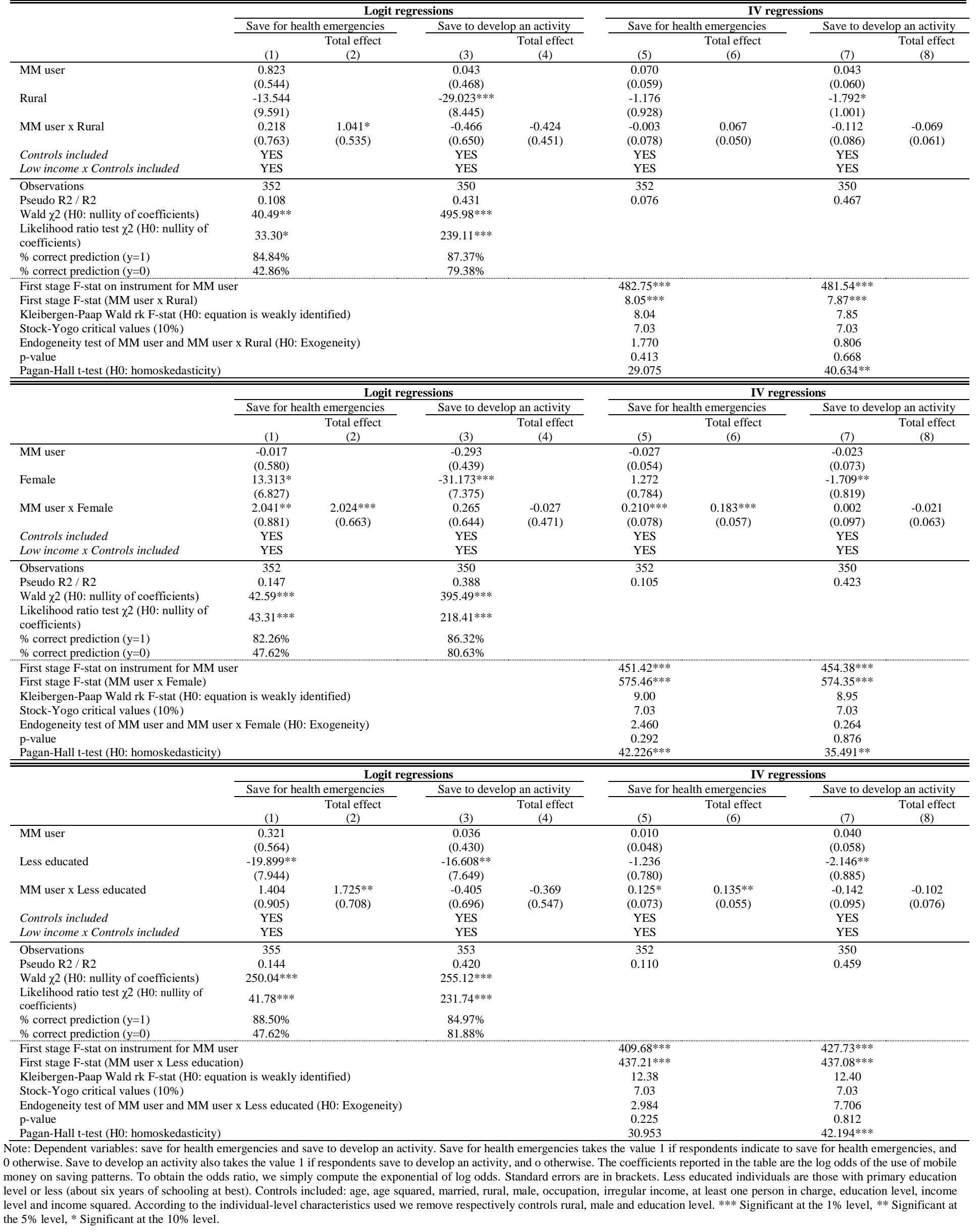


basis of their location, gender and education level ${ }^{29}$. It presents estimates of the relation between the use of mobile money and the propensity to save for health emergencies and saving to develop an activity by distinguishing individuals assumed to have low access from those assumed to have high access to formal financial instruments. Overall, the reported results indicate that while the use of mobile money does not make any difference in the saving behavior for relatively advantaged groups (urban, male and highly educated individuals), it does however increase the probability of saving for health emergencies for disadvantaged groups (rural, female and less educated individuals in columns 2). More precisely, our findings show that for individuals living in rural area, female or less educated, the propensity to save for health emergencies is respectively about 3, 6 and 4 times higher for mobile money users than for those who are not.

To sum up, our findings taken altogether show interestingly that mobile money technology may help bridge the gap between disadvantaged individuals who have less access to formal financial services and advantaged individuals and may hence foster financial inclusion. Indeed, mobile money appears to be attractive and appropriate for usually excluded groups (rural, female, individuals with less education and those who earn irregular incomes) to build their savings to face unexpected health emergencies ${ }^{30}$.

\section{Why mobile money may increase saving for health emergencies? Discussion of potential mechanisms}

One of our main results shows that a simple use/adoption of the mobile money technology increases people propensity to save for health emergencies. This result naturally raises the following question: Why is using mobile money positively and significantly associated with the propensity to save for health emergencies? - Is it due to the safety, low cost of services, quality

\footnotetext{
${ }^{29}$ Less educated individuals are those who have primary education level at best (about six years of schooling) and highly educated individuals those with secondary education level or more.

${ }^{30}$ Alternatively, in Appendix A.5.2, we use a survey data conducted on 1,000 people in Burkina Faso available in the Global Financial Inclusion Database (World Bank, 2015) in order to check the robustness of our main findings. While the GFI dataset allows us to replicate our core analysis, it does not however provide some key individual-level characteristics such as location or type of income.
} 
and/or accessibility of the mobile money? Since our data do not enable us to conclusively answer this question, we instead discuss in this section some conjectures as to possible answers.

We see two possible reasons why mobile money users are more likely to save for health emergencies than non-users. The first is that to save for health emergencies individuals need a saving account that allows them to avoid unneeded expenditures. Individuals hardly resist the temptation to spend on unnecessary items money they have at hand (Banerjee and Mullainathan 2010) which reduces their propensity to face healthcare expenses. The second explanation may be that people traditionally rely on saving mechanisms that require high degree of commitment (i.e. ROSCA) whereas saving for unpredictable events requires easy access to liquidity. Indeed, to liquidate land or livestock quickly and costlessly when a shock were to occur is not possible. Therefore, to deal with unanticipated illness shocks people need to save outside these illiquid assets. Mobile money provides people with an individual account that allows them to deposit it for free and securely. The networks of mobile money agents who insure cash in and cash out services allow users to access cash when the need arises. The mobile money providers, however, charge individuals $1 \%$ of the withdrawn amount. It is assumed that when individuals decide to save through their mobile money account, this involves implicitly their willing to support withdrawal fees. These fees may therefore play as a soft commitment which benefits individuals with selfcontrol issues to buildup savings by avoiding unneeded expenditures.

Shefrin and Thaler (1988) show that self-control problems, as a part of a broader set of time-inconsistent preferences, play a key role when studying saving behavior. Self-control implies that the trade-off between short term gratification and long term benefits entails a conflict that manifests through temptations. Individuals usually face "temptation goods" which give utility in the present but not in the future, and "non-temptation goods" which give utility both in the present and the future (Banerjee and Mullainathan, 2010). When people, particularly from poor countries such as Burkina Faso that we study, spend their money in "temptation goods" such as cigarettes, coffee, and alcohol, it becomes more difficult for them to put aside a portion of their money. Thus, reducing temptation through a commitment saving product should increase savings and consequently increase savers' financial capacity to face unpredictable events. However, the effectiveness of a saving product in overcoming these barriers depends on the type of commitment it provides. Dupas and Robinson (2013b) show that simply providing a saving technology with a 
soft commitment such as a box with a lock and key allows people to buildup savings for health emergencies. Meanwhile, Ashraf, Karlan and Yin (2010) find that providing individuals with a high commitment saving product affect people savings. They show that saving product that restricts withdrawals until people reach a specific goal or a specified month when large expenditures were expected, for example the beginning of school or Christmas, increased individuals' savings. These findings appear to reflect that soft commitment saving devices may be adequate to plan for unexpected events while a high commitment may be necessary for long term planning savings.

To provide evidence on the potential mechanisms through which mobile money users may have more propensity to save for health emergencies than non-users, we consider our model (2) and use the following specification:

$$
\begin{array}{r}
P R O B\left\{y_{i}=1\right\}=\Phi\left(\lambda_{1}+\lambda_{2} \text { MMuser }_{i}+\lambda_{3} \text { Motiv }_{i}+\lambda_{4} \text { MMuser }_{i} \times \text { Motiv }_{i}+\lambda_{5} \text { Motiv }_{i} \times I C_{i}+\lambda_{6} I C_{i}\right) \\
\text { where } \Phi \text { is the cumulative distribution function of logistic distribution }
\end{array}
$$

We consider the same dependent variable as in equation (2) where $y_{i}$ stands here only for save for health emergencies. $I C_{i}$ is similar to the vector for controls in equation (1). Motiv $v_{i}$ is our proxy of the independent variable of interest that we define as individuals' motivations to continue using or start using the mobile money. It derives from the following question "What are the reasons that could motivate you to continue using or start using the mobile money? " Each respondent rates the following five motivations: "A safe place to make deposits"; "Low cost of money transfers"; "Possibility of money transfers throughout the country"; "Possibility of money transfers within the sub-region (Ivory Coast)"; "An increase in the number of mobile money agents" using a 5-point Likert scale ranging from 1 (Not at all important) to 5 (Very important). We compute a dummy variable for each motivation which takes the value zero when the rating is 1 or 2 (not at all important and not important), and takes the value one when the rating is 3, 4 or 5 (moderately important, important or very important $)^{31}$. The coefficients of interest are $\lambda_{2}$ and the total effect given by $\lambda_{2}+\lambda_{4}$. If $\lambda_{2}$ and $\lambda_{2}+\lambda_{4}$ are positive and significant, then mobile money increases propensity to save for health emergencies irrespective of the strength of the motivation.

${ }^{31}$ Table A.2 in the Appendix presents descriptive statistics of the proxy for the five dummy variables. 
Table 6. Usage and perception of mobile money and saving for health emergencies.

\begin{tabular}{|c|c|c|c|c|c|c|c|c|c|c|}
\hline & \multicolumn{10}{|c|}{ Save for health emergencies } \\
\hline & \multicolumn{5}{|c|}{ Logit regressions } & \multicolumn{5}{|c|}{ IV regressions } \\
\hline & $\begin{array}{l}\text { Safe } \\
\text { place to } \\
\text { make } \\
\text { deposits } \\
\text { (1) }\end{array}$ & $\begin{array}{l}\text { Low } \\
\text { cost of } \\
\text { money } \\
\text { transfers } \\
\text { (2) }\end{array}$ & $\begin{array}{l}\text { Transfers } \\
\text { throughout } \\
\text { Burkina } \\
\text { Faso } \\
\text { (3) }\end{array}$ & $\begin{array}{l}\text { Transfer } \\
\text { within } \\
\text { the sub- } \\
\text { region } \\
\text { (CI) } \\
\text { (4) }\end{array}$ & $\begin{array}{l}\text { Increase } \\
\text { mobile } \\
\text { money } \\
\text { agent } \\
(5)\end{array}$ & $\begin{array}{l}\text { Safe place } \\
\text { to make } \\
\text { deposits } \\
\text { (6) }\end{array}$ & $\begin{array}{l}\text { Low cost } \\
\text { of money } \\
\text { transfers }\end{array}$ & $\begin{array}{c}\text { Transfers } \\
\text { throughout } \\
\text { Burkina } \\
\text { Faso } \\
\text { (8) }\end{array}$ & $\begin{array}{l}\text { Transfer } \\
\text { within } \\
\text { the sub- } \\
\text { region } \\
\text { (CI) } \\
\text { (9) }\end{array}$ & $\begin{array}{c}\text { Increase } \\
\text { mobile } \\
\text { money } \\
\text { agent } \\
(10)\end{array}$ \\
\hline MM user & $\begin{array}{c}0.548 \\
(1.074)\end{array}$ & $\begin{array}{l}3.574 * * \\
(1.648)\end{array}$ & $\begin{array}{c}0.811 \\
(1.890)\end{array}$ & $\begin{array}{l}-0.060 \\
(1.001)\end{array}$ & $\begin{array}{c}1.460 \\
(1.226)\end{array}$ & $\begin{array}{l}-0.073 \\
(0.116)\end{array}$ & $\begin{array}{c}0.435 \\
(0.297)\end{array}$ & $\begin{array}{c}0.221 \\
(0.381)\end{array}$ & $\begin{array}{l}-0.028 \\
(0.116)\end{array}$ & $\begin{array}{c}0.129 \\
(0.159)\end{array}$ \\
\hline Safe place to make deposits & $\begin{array}{l}-6.184 \\
(6.949)\end{array}$ & & & & & $\begin{array}{l}-0.882 \\
(0.705)\end{array}$ & & & & \\
\hline MM user x Safe place & $\begin{array}{c}0.799 \\
(1.230)\end{array}$ & & & & & $\begin{array}{l}0.223^{*} \\
(0.133)\end{array}$ & & & & \\
\hline Total effect & $\begin{array}{l}1.347^{* * *} \\
(0.600)\end{array}$ & & & & & $\begin{array}{c}0.150 * * \\
(0.065)\end{array}$ & & & & \\
\hline Low cost of money transfers & & $\begin{array}{l}-0.073 \\
(0.922)\end{array}$ & & & & & $\begin{array}{c}0.098 \\
(0.097)\end{array}$ & & & \\
\hline MM user $x$ Low cost & & $\begin{array}{l}-0.688 \\
(0.423)\end{array}$ & & & & & $\begin{array}{l}-0.097 \\
(0.079)\end{array}$ & & & \\
\hline Total effect & & $\begin{array}{l}2.886 * * \\
(1.242)\end{array}$ & & & & & $\begin{array}{c}0.340 \\
(0.219)\end{array}$ & & & \\
\hline $\begin{array}{l}\text { Transfers throughout Burkina } \\
\text { Faso }\end{array}$ & & & -0.203 & & & & & 0.057 & & \\
\hline & & & $(0.815)$ & & & & & $(0.095)$ & & \\
\hline $\begin{array}{l}\text { MM user x Transfers } \\
\text { throughout Burkina Faso }\end{array}$ & & & 0.004 & & & & & -0.039 & & \\
\hline Total effect & & & $\begin{array}{c}(0.491) \\
0.816 \\
(1.415)\end{array}$ & & & & & $\begin{array}{c}(0.096) \\
0.182 \\
(0.285)\end{array}$ & & \\
\hline $\begin{array}{l}\text { Transfer within the sub-region } \\
\text { (CI) }\end{array}$ & & & & -10.356 & & & & & -0.790 & \\
\hline & & & & $(8.182)$ & & & & & $(0.747)$ & \\
\hline $\begin{array}{l}\text { MM user } x \text { Transfer within the } \\
\text { sub-region }(\mathrm{CI})\end{array}$ & & & & 1.757 & & & & & 0.199 & \\
\hline Total effect & & & & $\begin{array}{c}(1.169) \\
1.697 * * * \\
(0.603)\end{array}$ & & & & & $\begin{array}{c}(0.143) \\
0.171 * * \\
(0.085)\end{array}$ & \\
\hline Increase mobile money agent & & & & & $\begin{array}{l}-1.162 \\
(0.863)\end{array}$ & & & & & $\begin{array}{l}-0.057 \\
(0.075)\end{array}$ \\
\hline $\begin{array}{l}\text { MM user } x \text { Increase mobile } \\
\text { money agent }\end{array}$ & & & & & -0.202 & & & & & -0.018 \\
\hline Total effect & & & & & $\begin{array}{c}(0.380) \\
1.258 \\
(0.877)\end{array}$ & & & & & $\begin{array}{c}(0.047) \\
0.112 \\
(0.114)\end{array}$ \\
\hline Controls included & YES & YES & YES & YES & YES & YES & YES & YES & YES & YES \\
\hline Motivations $x$ Controls included & YES & YES & YES & YES & YES & YES & YES & YES & YES & YES \\
\hline Observations & 351 & 350 & 351 & 351 & 351 & 351 & 350 & 351 & 351 & 351 \\
\hline Pseudo R2 & 0.175 & 0.145 & 0.126 & 0.164 & 0.134 & 0.123 & 0.103 & 0.088 & 0.112 & 0.081 \\
\hline $\begin{array}{l}\text { Wald } \chi^{2} \text { (H0: nullity of } \\
\text { coefficients) }\end{array}$ & $49.79 * * *$ & $43.30 * *$ & $39.17 * *$ & $42.13 * *$ & $43.45^{* *}$ & & & & & \\
\hline $\begin{array}{l}\text { Likelihood ratio test } \chi^{2} \text { (H0: } \\
\text { nullity of coefficients) }\end{array}$ & $50.52 * * *$ & $43.18^{* *}$ & $38.05^{* *}$ & $47.87 * * *$ & $40.20 * *$ & & & & & \\
\hline $\begin{array}{l}\% \text { correct prediction }(\mathrm{y}=1) \\
\% \text { correct prediction }(\mathrm{y}=0)\end{array}$ & $\begin{array}{l}72.49 \% \\
71.43 \%\end{array}$ & $\begin{array}{l}72.40 \% \\
66.67 \%\end{array}$ & $\begin{array}{l}70.55 \% \\
64.29 \%\end{array}$ & $\begin{array}{l}84.47 \% \\
61.90 \%\end{array}$ & $\begin{array}{l}66.02 \% \\
71.43 \%\end{array}$ & & & & & \\
\hline First stage F-stat on instrument for & MM user & & & & & $62.20 * * *$ & $61.35^{* * *}$ & $712.15^{* * *}$ & $23.68^{* * *}$ & $179.51^{* * *}$ \\
\hline First stage F-stat on instrument for & MM user $\mathrm{x}$ & Motivation & & & & $7.31 * * *$ & $25.97 * * *$ & $577.29 * * *$ & $5.21 * * *$ & $47.67 * * *$ \\
\hline Kleibergen-Paap Wald rk F-stat & & & & & & 10.96 & 53.89 & 2.32 & 22.64 & 68.37 \\
\hline Stock-Yogo critical values $(10 \%)$ & & & & & & 7.03 & 7.03 & 7.03 & 7.03 & 7.03 \\
\hline Endogeneity test of MM user and & MM user $\mathrm{x}$ & otivation & & & & 2.102 & 3.423 & 1.816 & 4.016 & 1.336 \\
\hline $\mathrm{p}$-value & & & & & & 0.350 & 0.181 & 0.403 & 0.134 & 0.513 \\
\hline Pagan-Hall t-test (H0: homoskeda & ticity) & & & & & $46.891 * * *$ & $35.409 *$ & 27.725 & $38.467 * *$ & 33.447 \\
\hline
\end{tabular}

Note: Dependent variable: Save for health emergencies, is a dummy that takes the value 1 if respondents indicate to save for health emergencies, and 0 otherwise. Robust standard errors are in brackets. Controls included: age, age squared, married, rural, male, occupation, irregular income, at least one person in charge, education level, income level and income squared. Table A.2 in the Appendix gives definitions and summary statistics of the independent variables. *** Significant at the $1 \%$ level, ** Significant at the 5\% level, * Significant at the $10 \%$ level. 
If $\lambda_{2}$ is not significant but $\lambda_{2}+\lambda_{4}$ is positive and significant, then mobile money increases this propensity only for users with strong motivation.

Our findings (Table 6) show that the coefficients of interest (total effect) related to the perception of mobile money as a safe place to make deposits and possibility to transfer money within the sub-region are positive and significant (columns 1 and 4). These findings imply that perception of mobile money as a safe place to make deposits and capable of facilitating money transfers within the sub-region (especially Ivory Coast) may be the channels through which the use of mobile money positively affects the likelihood to save for health emergencies. By contrast, both coefficients of interest related to the perceptions of mobile money as lowering cost of transfers being positive and significant (columns 3 and 4), it implies that for this motivation, differences in the perception do not distinguish mobile money users' propensity to save for health emergencies.

Mobile money users may cope with emergencies not only through savings but also through incoming remittances. Unfortunately, the way our survey was designed (the question we ask is whether individuals save to cope with health emergencies) does not allow us to check this other possible channel. Nevertheless, we examine and confirm previous evidence regarding the higher propensity of mobile money users to receive money transfers than non-users (Table 7). Several studies show that mobile money (i) increases the number and size of remittances by reducing the cost of money transfers, and (ii) allows mobile money users to face shocks compared to non-users (Batista and Vicente, 2016; Jack and Suri, 2014; Mbiti and Weil, 2011).

Overall, our findings suggest that one of the main reasons why mobile money users are more likely to save for health emergencies is because of safety that mobile money provides. These results support the findings of Dupas and Robinson (2013b) which indicate that providing people with a safe place to save increases savings for health emergencies. In addition, the possibility to easily transfer money within the sub-region, especially Ivory Coast, is also a factor that may explain the gap between mobile money users and non-users propensity to save for health emergencies ${ }^{32}$.

\footnotetext{
${ }^{32}$ Mobile money transfers within the sub-region especially Ivory Coast is then an important channel for the large community of Burkinabe immigrants to help family members in case of emergency. For more detail see footnote 4.
} 
Table 7. Receiving money transfers and mobile money. Full sample.

\begin{tabular}{|c|c|c|}
\hline & \multicolumn{2}{|c|}{ Receiving money transfers } \\
\hline & Logit regressions & IV regressions \\
\hline & (1) & (2) \\
\hline \multirow[t]{2}{*}{ MM user } & $1.828 * * *$ & $0.405^{* * *}$ \\
\hline & $(0.287)$ & $(0.051)$ \\
\hline \multirow[t]{2}{*}{ Age } & $0.351 * * *$ & $0.063^{* * *}$ \\
\hline & $(0.136)$ & $(0.023)$ \\
\hline \multirow[t]{2}{*}{ Age squared } & $-0.005^{* * *}$ & $-0.001 * * *$ \\
\hline & $(0.002)$ & $(0.000)$ \\
\hline \multirow[t]{2}{*}{ Married } & -0.018 & -0.012 \\
\hline & $(0.313)$ & $(0.056)$ \\
\hline \multirow[t]{2}{*}{ Rural } & $-1.086^{* * *}$ & $-0.201 * * *$ \\
\hline & $(0.310)$ & $(0.049)$ \\
\hline \multirow[t]{2}{*}{ Male } & 0.117 & 0.024 \\
\hline & $(0.261)$ & $(0.045)$ \\
\hline \multirow[t]{2}{*}{ Occupation } & $-1.148 * *$ & $-0.191 * *$ \\
\hline & $(0.523)$ & $(0.084)$ \\
\hline \multirow[t]{2}{*}{ Irregular income } & $0.768 * *$ & $0.128 * *$ \\
\hline & $(0.313)$ & $(0.053)$ \\
\hline \multirow[t]{2}{*}{ Person in charge } & 0.086 & 0.008 \\
\hline & $(0.248)$ & $(0.044)$ \\
\hline \multirow[t]{2}{*}{ Education } & 0.127 & 0.013 \\
\hline & $(0.160)$ & $(0.030)$ \\
\hline \multirow[t]{2}{*}{ Income } & $2.353 * *$ & $0.445^{* * *}$ \\
\hline & $(0.914)$ & $(0.152)$ \\
\hline \multirow[t]{2}{*}{ Income squared } & $-0.361 * *$ & $-0.069 * * *$ \\
\hline & $(0.150)$ & $(0.026)$ \\
\hline \multirow[t]{2}{*}{ Constant } & $-8.391 * * *$ & $-1.035 * *$ \\
\hline & $(2.397)$ & $(0.409)$ \\
\hline Observations & 374 & 374 \\
\hline Pseudo R2 / R2 & 0.202 & 0.237 \\
\hline Wald $\chi^{2}$ (H0: nullity of coefficients) & $63.81 * * *$ & \\
\hline Likelihood ratio test $\chi^{2}$ (H0: nullity of coefficients) & $123.19 * * *$ & \\
\hline$\%$ correct prediction $(\mathrm{y}=1)$ & $74.90 \%$ & \\
\hline$\%$ correct prediction $(\mathrm{y}=0)$ & $66.67 \%$ & \\
\hline First stage F-stat on instrument for MM user & & $55.44 * * *$ \\
\hline Kleibergen-Paap Wald rk F-stat (H0: equation is weakly identified) & & 55.44 \\
\hline Stock-Yogo critical values (10\%) & & 16.38 \\
\hline Endogeneity test of MM user (H0: Exogeneity) & & 2.297 \\
\hline p-value & & 0.130 \\
\hline Pagan-Hall t-test (H0: homoskedasticity) & & 12.909 \\
\hline
\end{tabular}

Note: Dependent variable: Receiving money transfers is a dummy variable that equals 1 if respondents receive money transfers, and 0 otherwise. Robust standard errors are in brackets. Controls included: age, age squared, married, rural, male, occupation, irregular income, at least one person in charge, education level, income level and income squared. *** Significant at the $1 \%$ level, ** Significant at the 5\% level, * Significant at the $10 \%$ level. 


\section{Conclusion}

In Burkina Faso as well as in other less developed countries, limited access to formal financial services lead people to rely mainly on informal finance. In the presence of predominant use of informal savings mechanisms, self-insurance against unexpected life events such as health shocks can be unmet. This may lower productivity which in turn negatively impacts the economic activity and growth. In this context, providing people with a convenient device to save can reduce their vulnerabilities to health emergencies. In low income countries, financial access have important implications on people well-being and poverty reduction.

The objective of this paper is to analyze the impact of mobile money as a soft commitment device on saving behavior. We use an original dataset from a survey we conducted in Burkina Faso using $50 \%$ of mobile money users and $50 \%$ of non-users. Our results are consistent with previous findings on the effects of soft commitment devices on the propensity to save for health emergencies. In line with Dupas and Robinson (2013b), we find that the use of mobile money increases the likelihood of individuals to save for health emergencies. Indeed, mobile money users are more prone to save for unexpected health shocks than non-users, while there is no difference between users and non-users of mobile money to save for predictable events. Taking into account disparities in financial access, we show that mobile money increases the propensity of rural, female, less educated and individuals with irregular income to save for health emergencies. In our further investigations, we address the issue about the possible mechanisms or pathways through which using mobile money helps increase the propensity to save for health emergencies. We find that safety and the possibility to transfer money within the sub-region associated with mobile money to count among possible explanations.

The potential for mobile technology and mobile money specifically to transform the lives of the poor, while palpable, is so far little documented. Governments and especially Central Banks in developing countries have done a lot in this sense to increase the supply of mobile money services throughout the country. However, despite these efforts, mobile money adoption remains low in some countries such as Burkina Faso compared to the success in Kenya or that of the neighbor Ivory Coast. This low adoption may stem from the existing inconsistencies of legal and regulatory framework of electronic money system in Burkina Faso (Musuku et al., 2011). Hence, putting in place consistent policy and regulatory reforms that cover all mobile money services and providers may foster mobile money system development and improve formal financial inclusion. 
Moreover, specific strategies are needed to increase the access and usage of mobile money. One leverage on which Central Banks may act is through the expansion of electronic money issuers and retailer agents. By doing so, it may reinforce competitiveness in the financial system and hence reduce costs and increase efficiency. The involvement of governments in the development of mobile money can also increase the confidence of the population to adopt this new financial innovation. More specifically, partnerships could be established between governments and mobile money issuers for employee's payments and for the collection of taxes. The traceability of the various operations conducted through mobile money could also be put forward for the credibility of this new system.

Nevertheless, a key outstanding question left for future investigation is what this innovative savings product would do to existing use of financial mechanisms such as the use of informal and formal finance. An empirical study of De Koker and Jentzsch (2013) on the role of transparency in the usage of formal or informal finance in eight African countries finds that a share of the population continues to use informal services despite being "financially included" customers. Hence, an increase in access to formal services such as mobile banking does not necessarily result in an immediate reduction of usage of informal services. Future research is needed to provide evidence on the role of mobile money as a complement or substitute of formal and/or informal finance. 


\section{References}

Aker, J. C. and Isaac M. Mbiti (2010) "Mobile Phones and Economic Development in Africa." Journal of Economic Perspectives 24(3):207-32.

Allen, F., C. Elena, C. Robert, Q. Jun, S. Lemma and V. Patricio (2014) "The African Financial Development and Financial Inclusion Gaps.” Journal of African Economies 23(5):614-42.

Ambec, S. and N. Treich (2007) "Roscas as Financial Agreements to Cope with Self-Control Problems." Journal of Development Economics 82:120-37.

Angrist J. D. and J. S. Pischke (2008) "Mostly Harmless Econometrics: An Empiricist' S Companion." Massachusettts I nstitute of Technology and The London school of Economics (March):290.

Ashraf, N., D. Karlan and W. Yin (2010) "Female Empowerment: Impact of a Commitment Savings Product in the Philippines." World Development 38:333-44.

Banerjee, A. and S. Mullainathan (2010) "The Shape of Temptation: Implications for the Economic Lives of the Poor." National Bureau of Economic Research Working Paper Series 1-49.

Banerjee, A. and E. Duflo (2007) "The Economic Lives of the Poor." Journal of Economic Perspectives 21(1):1-22.

Batista, C. and P. C. Vicente (2016) "Introducing Mobile Money in Rural Mozambique: Evidence from a Field Experiment." Working Paper.

Baum, C. F., M. E. Schaffer and S. Stillman (2007) "Enhanced Routines for Instrumental Variables/generalized Method of Moments Estimation and Testing." The Stata Journal 7(4):465-506.

Banque Centrale des Etats de l'Afrique de l'Ouest (BCEAO). 2011. Rapport Annuel de La Commission Bancaire.

Beck, T., A. Demirgüç-Kunt and P. Honohan (2009) “Access to Financial Services: Measurement, Impact, and Policies.” World Bank Research Observer 24:119-45.

Blumenstock, J. E., M. Callen and L. Koepke (2015) "Promises and Pitfalls of Mobile Money in Afghanistan: Evidence from a Randomized Control Trial." Working Paper, Washington University.

Chowa, G., R. Masa and M. Sherraden (2012) "Wealth Effects of an Asset-Building Intervention Among Rural Households in Sub-Saharan Africa." Journal of the Society for Social Work and Research 3(4):329-45.

Christen, B. and I. Mas (2009) "It's Time to Address the Microsavings Challenge, Scalably." Enterprise Development and Microfinance 20:274-85. 
Collins, D., J. Morduch, S. Rutherford and O. Ruthven (2009) Portfolios of the Poor: How the World's Poor Live on \$2 a Day. Princeton University Press.

Consortium on Financial Systems and Poverty. 2013. "The Rise and Impact of M-PESA." Research Brief 1:1-8.

Demirguc-kunt, A. and L. Klapper (2012) "Measuring Financial Inclusion. The Global Findex Database.' Policy research working paper, World Bank 6025(April):1-61.

Demirgüç-Kunt, A., L. Klapper and D. Singer (2013) "Financial Inclusion and Legal Discrimination against Women: Evidence from Developing Countries." World Bank Policy Working Paper 6416 (April).

Demombynes, G. and A. Thegeya (2012) "Kenya's Mobile Revolution and the Promise of Mobile Savings.” World Bank Policy Research Working Paper 5988 (March).

Dermish, A., C. Kneiding, P. Leishman and I. Mas (2012) "Branchless and Mobile Banking Solutions for the Poor: A Survey of the Literature." Innovations: Technology, Governance, Globalization 6(4):81-98.

Dupas, P., S. Green, A. Keats and J. Robinson (2012) "Challenges in Banking the Rural Poor: Evidence from Kenya’s Western Province.” NBER Working Paper No. 17851.

Dupas, P. and J. Robinson (2013a) "Savings Constraints and Microenterprise Development: Evidence from a Field Experiment in Kenya." American Economic Journal: Applied Economics 5(1):163-92.

Dupas, P. and J. Robinson (2013b) "Why Don't the Poor Save More? Evidence from Health Savings Experiments.” American Economic Review 103:1138-71.

Eijkman, F., J. Kendall and I. Mas (2010) "Bridges to Cash: The Retail End of M-Pesa." Savings and Development 34(2):219-52.

Freedman, D. A. (2006) “On The So-Called 'Huber Sandwich Estimator' and 'Robust Standard Errors." The American Statistician 60(4):299-302.

Garg, N. (2011) “Pricing for E/M-Banking.” MicroSave Briefing Note \# 107 1-2.

Hulme, D., K. Moore and A. Barrientos (2009) "Assessing the Insurance Role of Microsavings." DESA Working Paper 83.

Jack, W. and T. Suri (2011) "Mobile Money: The Economics of M-PESA 1." National Bureau of Economic Research Working Paper 16721 1-30.

Jack, W. and T. Suri (2014) "Risk Sharing and Transactions Costs: Evidence from Kenya's Mobile Money Revolution.” American Economic Review 104:183-223.

Karlan, D. and J. Morduch (2009) "Access to Finance.” NYU Wagner Research Paper No. 2011 - 
03. $1-86$.

Karlan, D., A. L. Ratan and J. Zinman (2014) "Savings by and for the Poor: A Research Review and Agenda." Review of Income and Wealth 60(1):36-78.

Kendall, J. (2010) “A Penny Saved: How Do Savings Accounts Help the Poor?” Financial Access Initiative, Focus Note (2005):1-22.

De Koker, L. and N. Jentzsch (2013) "Financial Inclusion and Financial Integrity: Aligned Incentives?" World Development 44:267-80.

Lonie, S., M. Martinez and R. Oulai (2013) "Overview of COTE D' IVOIRE: Mobile Financial Services Market Data 2013.” International Finance Corporation, World Bank Group.

Lusardi, A. and O. S. Mitchell (2014) "The Economic Importance of Financial Literacy: Theory and Evidence." Journal of Economic Literature 52(1):5-44.

Mas, I. (2010) “Savings for the Poor.” World Economics 11(4):1-12.

Mas, I. and K. Kumar (2008) "Banking on Mobiles: Why, How, for Whom?” Consultative Group to Assist the Poor, Focus Note, No. 48 (June):1-28.

Mas, I. and C. Mayer (2011) "Savings as Forward Payments : Innovations on Mobile Money Platforms." Forthcoming as Chapter 10 in "Financial inclusion for poverty alleviation: Banking on the unbanked." Essam Yassin Mohammed and Zenebe Bashaw Uraguchi (eds). London: Routledge. (September):1-14.

Mbarathi, N. and D. Kathleen (2014) "Savings and Mobile Banking Services amongst Poor Women within Kenya's Rural Agricultural Sector."

Mbiti, I. and D. Weil (2011) "Mobile Banking: The Impact of M-Pesa in Kenya." NBER Working Paper No. 17129.

Mbiti, I. and D. N. Weil (2011) "Mobile Banking: The Impact of M-PESA in Kenya." National Bureau of Economic Research.

Mbiti, I. and D. N. Weil (2013) "The Home Economics of E-Money: Velocity, Cash Management, and Discount Rates of M-Pesa Users.” American Economic Review 103(3):369-74.

Morawczynski, O. (2009) "Saving Through the Mobile Phone - The Case of M-PESA." MicroBanking Bulletin (19):7-14.

Morawczynski, O. and M. Pickens (2009) "Poor People Using Mobile Financial Services: Observations on Customer Usage and Impact from M-PESA.” Consultative Group to Assist the Poor (August).

Munyegera, G. K. and T. Matsumoto (2016) "Mobile Money, Remittances, and Household Welfare: Panel Evidence from Rural Uganda.” World Development 79:127-37. 
Musuku, T. B., M. Chiara and A. M. Mason (2011) "Lowering the Cost of Payments and Money Transfers in UEMOA Africa Trade Policy Notes." World Bank, Africa Trade Policy Notes, Notes \#23 1-9.

Ondiege, P. (2010) "Mobile Banking in Africa: Taking the Bank to the People." Africa Economic Brief 1(8).

Rutherford, S. (2002) "Money Managers: The Poor and Their Savings." MicroSave Briefing Note \# 13 1-2.

Shefrin, H. M. and R. H. Thaler (1988) "The Behavioral Life-Cycle Hypothesis." Economic Inquiry 26(4):609-43.

Smets, P. (2000) "ROSCAs as a Source of Housing Finance for the Urban Poor: An Analysis of Self-Help Practices from Hyderabad, India.” Community Development Journal 35(1):16-30.

The World Bank Group (2015) Data (online), www.data.worldbank.org

The Global Financial Inclusion (Global Findex) Database, World Bank Group (2015). www.datatopics.worldbank.org

Wooldridge, J. M. (2002) "Econometric Analysis of Cross Section and Panel Data." The MIT Press. 


\section{Appendix}

Table A.1. Correlation matrix for the full sample.

\begin{tabular}{|c|c|c|c|c|c|c|c|c|c|c|c|c|c|c|c|c|c|}
\hline & $\begin{array}{c}\text { Save for } \\
\text { unpredictable } \\
\text { events }\end{array}$ & $\begin{array}{c}\text { Save for } \\
\text { health } \\
\text { emergencies }\end{array}$ & $\begin{array}{l}\text { Save for } \\
\text { predictable } \\
\text { purposes }\end{array}$ & $\begin{array}{l}\text { Save to } \\
\text { develop an } \\
\text { activity }\end{array}$ & $\begin{array}{l}\text { MM } \\
\text { user }\end{array}$ & Distance & Age & $\begin{array}{c}\text { Age } \\
\text { squared }\end{array}$ & Married & Rural & Male & Occupation & $\begin{array}{l}\text { Irregular } \\
\text { income }\end{array}$ & $\begin{array}{l}\text { At least one } \\
\text { person in } \\
\text { charge }\end{array}$ & Education & Income & $\begin{array}{l}\text { Income } \\
\text { squared }\end{array}$ \\
\hline $\begin{array}{l}\text { Save for } \\
\text { unpredictable } \\
\text { events }\end{array}$ & 1 & & & & & & & & & & & & & & & & \\
\hline $\begin{array}{l}\text { Save for } \\
\text { health } \\
\text { emergencies }\end{array}$ & 0.768 & 1 & & & & & & & & & & & & & & & \\
\hline $\begin{array}{l}\text { Save for } \\
\text { predictable } \\
\text { purposes }\end{array}$ & -0.006 & 0.076 & 1 & & & & & & & & & & & & & & \\
\hline $\begin{array}{l}\text { Save to } \\
\text { develop an } \\
\text { activity }\end{array}$ & -0.108 & -0.043 & 0.534 & 1 & & & & & & & & & & & & & \\
\hline MM user & 0.146 & 0.151 & -0.089 & -0.086 & 1 & & & & & & & & & & & & \\
\hline Distance & -0.088 & -0.096 & 0.127 & 0.069 & -0.888 & 1 & & & & & & & & & & & \\
\hline Age & 0.074 & 0.125 & 0.208 & 0.184 & -0.027 & 0.043 & 1 & & & & & & & & & & \\
\hline Age squared & 0.068 & 0.115 & 0.200 & 0.154 & -0.045 & 0.060 & 0.990 & 1 & & & & & & & & & \\
\hline Married & 0.066 & 0.088 & 0.132 & 0.102 & 0.131 & -0.070 & 0.607 & 0.579 & 1 & & & & & & & & \\
\hline Rural & 0.010 & 0.064 & -0.055 & 0.041 & 0.146 & -0.088 & 0.251 & 0.245 & 0.226 & 1 & & & & & & & \\
\hline Male & 0.028 & 0.026 & 0.020 & 0.030 & 0.007 & 0.009 & 0.267 & 0.254 & 0.107 & 0.032 & 1 & & & & & & \\
\hline Occupation & -0.048 & 0.083 & 0.256 & 0.390 & -0.078 & 0.069 & 0.430 & 0.384 & 0.348 & 0.158 & 0.114 & 1 & & & & & \\
\hline $\begin{array}{l}\text { Irregular } \\
\text { income }\end{array}$ & -0.081 & -0.006 & 0.211 & 0.472 & 0.042 & -0.030 & 0.100 & 0.080 & 0.105 & 0.302 & -0.096 & 0.197 & 1 & & & & \\
\hline $\begin{array}{l}\text { At least one } \\
\text { person in } \\
\text { charge }\end{array}$ & 0.036 & 0.002 & 0.061 & 0.056 & 0.107 & -0.097 & -0.002 & -0.009 & 0.024 & -0.030 & -0.008 & 0.047 & 0.015 & 1 & & & \\
\hline Education & 0.143 & 0.074 & -0.051 & -0.336 & 0.162 & -0.126 & -0.147 & -0.139 & -0.169 & -0.227 & 0.017 & -0.391 & -0.358 & -0.013 & 1 & & \\
\hline Income & -0.001 & 0.069 & 0.206 & 0.179 & 0.071 & -0.043 & 0.441 & 0.426 & 0.358 & -0.052 & 0.271 & 0.342 & -0.131 & 0.055 & 0.127 & 1 & \\
\hline $\begin{array}{l}\text { Income } \\
\text { squared }\end{array}$ & 0.007 & 0.070 & 0.201 & 0.172 & 0.070 & -0.047 & 0.427 & 0.417 & 0.349 & -0.078 & 0.255 & 0.297 & -0.145 & 0.063 & 0.135 & 0.976 & 1 \\
\hline
\end{tabular}




\section{Table A.2. Summary statistics and variables description (Mechanisms)}

Variable

Safe place to make

deposits

Low cost of

transfers

Transfers

throughout Burkina

Faso

Transfers within

the sub-region

(Ivory Coast)

Increase the

number of mobile

money agents
Definition

Obs. Mean

Proxies of the usage of money transfers services

Receiving money

transfers
Indicate respondent's perception of mobile money as safe place to make deposits, encoded as (Moderately important, important, and very important $)=1$, (Not at all important and not important) $=0$,

Indicate respondent's perception of mobile money as lowering cost of money transfer, encoded as (Moderately important, important, and very important $)=1$, (Not at all important and not very important $)=0$

Indicate respondent's perception of mobile money as allowing money transfers throughout Burkina Faso, encoded as $($ Not at all important $)=1,($ Not important $)=2,($ Moderately important $)=3,($ Important $)=4,($ Very important $)=$

Indicate respondent's perception of mobile money as allowing money transfers from the sub-region, especially from Ivory Coast, encoded as (Moderately important, important, and very important) $=1$, (Not at all important and not very important) $=0$

Indicate respondent's perception of an increase of mobile money agents, encoded as (Moderately important, important, and very important $)=1$, (Not at all important and not very important $)=0$ 


\section{A.5. External validity and representativeness}

\section{A.5.1. External validity}

In the paper, we explain that our survey was conducted in the central region of Burkina Faso. Why was it chosen? How different is this region from the other Burkina's regions? In Burkina Faso there are 13 regions that consist of some urban where formal financial institutions are generally concentrated, and many rural ones ${ }^{33}$ that are underserved or some without any formal financial institutions. Being the second region in terms of the number of mobile money agents, we chose the central region for budgetary reasons but also to increase our chance to find respondents who use mobile money services. Thus, our study allows us to analyze the effects of using mobile money on people saving behavior where formal financial services are supposed to be available (urban areas) and also where they are supposed to be less developed or inexistent (rural areas).

To provide some highlights about the similarities or differences between the 13 regions of Burkina Faso, we report data on formal financial institutions access by regions (Table A.5.1). Data on individuals' saving behavior and the number of mobile money accounts by region are not available. Where the data are available, we report the share of population and that of formal financial institutions located in each region (2012) as an indicator of access to formal financial services, and the number of mobile money agents (2014). Table A.5.1 shows that central region is the most populated region with $13 \%$ of the population located in this area. Regarding the geographical breakdown of financial institutions, the data on banks are available only for the central region where about $36 \%$ of banks are located. Microfinance and credit union institutions are more concentrated in western part of the country (Boucle du Mouhoun) with respectively $21 \%$ and $16 \%$. The available record on mobile money agents reveals that Boucle du Mouhoun has the highest number of mobile money agents with more than twice of that of the central region.

\footnotetext{
${ }^{33}$ Generally, there is one urban area divided into many urban districts. For instance, in the central region, one urban area is divided into 12 urban districts, and 6 rural areas are divided into 172 rural districts.
} 
Table A.5.1. Access to formal financial services by region in Burkina Faso.

\begin{tabular}{|c|c|c|c|c|c|}
\hline \multirow{2}{*}{ Region } & Population & Banks & Microfinance & Credit union & $\begin{array}{r}\text { Mobile money } \\
\text { agents }\end{array}$ \\
\hline & \multicolumn{3}{|c|}{2012} & \multicolumn{2}{|r|}{2014} \\
\hline $\begin{array}{l}\text { Boucle du } \\
\text { Mouhoun }\end{array}$ & $10 \%$ & $\mathrm{Na}$ & $21 \%$ & $16 \%$ & 238 \\
\hline Cascades & $4 \%$ & $\mathrm{Na}$ & $2 \%$ & $5 \%$ & na \\
\hline Centre & $13 \%$ & $36 \%$ & $9 \%$ & $12 \%$ & 152 \\
\hline Centre-Est & $8 \%$ & $\mathrm{Na}$ & $4 \%$ & $10 \%$ & na \\
\hline Centre-Nord & $8 \%$ & $\mathrm{Na}$ & $7 \%$ & $5 \%$ & na \\
\hline Centre-Ouest & $8 \%$ & $\mathrm{Na}$ & $10 \%$ & $5 \%$ & na \\
\hline Centre-Sud & $4 \%$ & $\mathrm{Na}$ & $7 \%$ & $2 \%$ & na \\
\hline Est & $9 \%$ & $\mathrm{Na}$ & $5 \%$ & $8 \%$ & 34 \\
\hline Hauts-Bassins & $11 \%$ & $\mathrm{Na}$ & $12 \%$ & $13 \%$ & na \\
\hline Nord & $8 \%$ & $\mathrm{Na}$ & $9 \%$ & $9 \%$ & 43 \\
\hline Palreau-Central & $5 \%$ & $\mathrm{Na}$ & $2 \%$ & $3 \%$ & na \\
\hline Sahel & $7 \%$ & $\mathrm{Na}$ & $10 \%$ & $6 \%$ & na \\
\hline Sud-Ouest & $4 \%$ & $\mathrm{Na}$ & $3 \%$ & $6 \%$ & na \\
\hline
\end{tabular}

Source: Ministère de l'Economie et des Finances, 2014. The number of mobile money agents is provided by the mobile money provider Airtel money as of 2014. The terminology "Central region" used throughout the paper corresponds to the region "Centre" of this Table. 


\section{A.5.2. Impact of mobile money on individuals' saving behavior using an alternative source of data.}

We use a survey data conducted on 1,000 people in Burkina Faso available in the Global Financial Inclusion Database (World Bank, 2015) in order to check the robustness of our main findings. While the database has the advantage of covering the whole country ${ }^{34}$, it remains limited in providing individual-level characteristics such as location or type of income but allows us to replicate our core analysis.

Table A.5.2 presents the results. We use a logit model that mimics our equations (1) and (2) and two dependent variables for save for emergency and save to develop an activity. While the survey does not precisely identify savings for health emergencies, we define a proxy, save for emergency, indicating how individuals cope with an emergency. This proxy is a dummy variable that equals to one if respondents indicate that it is very possible to come up with emergency funds through savings, and equals to zero otherwise. For the second dependent variable, save to develop an activity, we define a proxy that indicates if individuals save to start, operate, or grow a business or farm. This proxy is also a dummy that equals to one if respondents indicate that they saved to start, operate, or grow a business or farm, and equals to zero otherwise. We control for age, gender, education level, and income quintile. Due to lack of data, we only examine the heterogeneity of effects of mobile money on individuals' saving behavior by considering low vs. high income, female vs. male, and less vs. highly educated individuals.

Overall, consistent with our findings, the results show that the use of mobile money increases the propensity of individuals to save for emergencies. The results also show that mobile money increases the propensity to save for emergencies especially for female and less educated individuals supporting our findings on disadvantaged groups.

\footnotetext{
${ }^{34}$ Individual probability weights are used to make the sample nationally representative.
} 
Table A.5.2. Saving choices and mobile money: using Global Financial Inclusion Database.

\begin{tabular}{|c|c|c|c|c|c|c|c|}
\hline & \multicolumn{7}{|c|}{ Save for health emergencies } \\
\hline & $\begin{array}{c}\text { Full } \\
\text { sample }\end{array}$ & \multicolumn{2}{|c|}{ Low vs. High income } & \multicolumn{2}{|c|}{ Female vs. Male } & \multicolumn{2}{|c|}{ Less vs. Highly educated } \\
\hline & $(1)$ & $(2)$ & $\begin{array}{l}\text { Total } \\
\text { effect } \\
(3)\end{array}$ & (4) & $\begin{array}{c}\text { Total } \\
\text { effect } \\
(5) \\
\end{array}$ & $(6)$ & $\begin{array}{l}\text { Total } \\
\text { effect } \\
(7) \\
\end{array}$ \\
\hline MM user & $\begin{array}{l}0.945^{* *} * \\
(0.378)\end{array}$ & $\begin{array}{l}0.829 * * \\
(0.405)\end{array}$ & & $\begin{array}{c}0.357 \\
(0.450)\end{array}$ & & $\begin{array}{c}0.389 \\
(0.473)\end{array}$ & \\
\hline Individuals' characteristics & & $\begin{array}{l}1.323 \\
(1.705)\end{array}$ & & $\begin{array}{l}-1.685 \\
(1.963)\end{array}$ & & $\begin{array}{l}-0.585 \\
(1.956)\end{array}$ & \\
\hline MM user x Individuals' & & 0.215 & 1.044 & 1.123 & $1.480 * *$ & 0.910 & $1.299 * *$ \\
\hline \multirow{3}{*}{$\begin{array}{l}\text { Controls included } \\
\text { Individuals' characteristics } \\
x \text { Controls included }\end{array}$} & & $(0.802)$ & $(0.692)$ & $(0.780)$ & $(0.637)$ & $(0.765)$ & $(0.601)$ \\
\hline & YES & YES & & YES & & YES & \\
\hline & YES & YES & & YES & & YES & \\
\hline Observations & 846 & 846 & & 846 & & 846 & \\
\hline Pseudo R2 & 0.078 & 0.071 & & 0.082 & & 0.085 & \\
\hline $\begin{array}{l}\text { Wald } \chi^{2} \text { (H0: nullity of } \\
\text { coefficients) }\end{array}$ & $43.26 * * *$ & $47.60 * * *$ & & $44.00 * * *$ & & $70.98 * * *$ & \\
\hline \multirow[t]{4}{*}{$\begin{array}{l}\text { Likelihood ratio test } \chi^{2} \text { (H0: } \\
\text { nullity of coefficients) }\end{array}$} & $166.44 * * *$ & $160.24 * * *$ & & $170.35 * * *$ & & $172.92 * * *$ & \\
\hline & \multicolumn{7}{|c|}{ Save to develop an activity } \\
\hline & $\begin{array}{c}\text { Full } \\
\text { sample }\end{array}$ & \multicolumn{2}{|c|}{ Low vs. High income } & \multicolumn{2}{|c|}{ Female vs. Male } & \multicolumn{2}{|c|}{ Less vs. Highly educated } \\
\hline & (1) & (2) & $\begin{array}{l}\text { Total } \\
\text { effect } \\
(3)\end{array}$ & (4) & $\begin{array}{l}\text { Total } \\
\text { effect } \\
(5)\end{array}$ & (6) & $\begin{array}{l}\text { Total } \\
\text { effect } \\
(7)\end{array}$ \\
\hline MM user & $\begin{array}{c}0.425 \\
(0.473)\end{array}$ & $\begin{array}{l}-0.433 \\
(0.474)\end{array}$ & & $\begin{array}{l}0.987^{*} \\
(0.586)\end{array}$ & & $\begin{array}{c}0.929 * * \\
(0.473)\end{array}$ & \\
\hline Individuals' characteristics & & $\begin{array}{l}-1.543 \\
(2.367)\end{array}$ & & $\begin{array}{l}-3.091 \\
(2.656)\end{array}$ & & $\begin{array}{l}0.487 \\
(4.245)\end{array}$ & \\
\hline \multirow[t]{2}{*}{$\begin{array}{l}\text { MM user x Individuals, } \\
\text { characteristics }\end{array}$} & & $2.016^{* *}$ & $1.583^{* *} *$ & -1.392 & -0.405 & -0.802 & 0.127 \\
\hline & & $(0.921)$ & $(0.789)$ & $(1.005)$ & $(0.816)$ & $(0.875)$ & $(0.736)$ \\
\hline \multirow{2}{*}{$\begin{array}{l}\text { Controls included } \\
\text { Individuals' characteristics } \\
x \text { Controls included }\end{array}$} & YES & YES & & YES & & YES & \\
\hline & YES & YES & & YES & & YES & \\
\hline Observations & 999 & 999 & & 999 & & 999 & \\
\hline Pseudo R2 & 0.096 & 0.099 & & 0.102 & & 0.098 & \\
\hline $\begin{array}{l}\text { Wald } \chi 2 \text { (H0: nullity of } \\
\text { coefficients) }\end{array}$ & $55.40 * * *$ & $44.43^{* * * *}$ & & $56.94 * * *$ & & $81.45^{* * * *}$ & \\
\hline $\begin{array}{l}\text { Likelihood ratio test } \chi^{2}(\mathrm{H} 0 \text { : } \\
\text { nullity of coefficients) }\end{array}$ & $82.24 * * *$ & $84.66^{* * * *}$ & & $87.40 * * *$ & & $83.71 * * *$ & \\
\hline
\end{tabular}

Note: Dependent variables: save for emergency and save to develop an activity are all dummies. Save for emergency equals to 1 if respondents indicate coming up with emergency funds through savings, and 0 otherwise. Save to develop an activity equals to 1 if respondents indicate save to start, operate, or grow business or farm, and 0 otherwise. The variable of interest, MM user is a binary variable that takes the value 1 if respondents has mobile money account, and 0 otherwise. To obtain the odds ratio, we simply compute the exponential of log odds. Robust standard errors are in brackets. Controls included: age, age squared, female, education level, income quintile and income quintile squared. According to the individuallevel characteristics we remove respectively controls income quintile and income quintile squared, female and education level. $* * *$ Significant at the $1 \%$ level, ** Significant at the $5 \%$ level, * Significant at the $10 \%$ level. 


\section{A.6. Transaction fees of mobile money services}

Table A.6.1 Fees associated with mobile money cash in / cash out functions and transfers services as of 2013.

\begin{tabular}{|c|c|c|c|c|}
\hline Mobile Money & Services & Minimum amount & Maximum amount & Fees (FCFA) \\
\hline Cash in & (deposits) & 500 & 5000000 & 0 \\
\hline \multirow{6}{*}{ Cash out } & \multirow{6}{*}{ (withdrawals) } & 500 & 5000 & 350 \\
\hline & & 5001 & 25000 & 600 \\
\hline & & 25001 & 50000 & 900 \\
\hline & & 50001 & 100000 & 1500 \\
\hline & & 100001 & 200000 & 2000 \\
\hline & & 200001 & 5000000 & $1 \%$ \\
\hline \multirow{11}{*}{ Transfers } & \multirow{5}{*}{$\begin{array}{l}\text { Mobile money user to } \\
\text { Mobile money user }\end{array}$} & 500 & 10000 & 100 \\
\hline & & 10001 & 50000 & 200 \\
\hline & & 50001 & 100000 & 400 \\
\hline & & 100001 & 300000 & 600 \\
\hline & & 300001 & 5000000 & $0,20 \%$ \\
\hline & \multirow{6}{*}{$\begin{array}{l}\text { Mobile money user to Non } \\
\text { mobile money user }\end{array}$} & 1000 & 5000 & 600 \\
\hline & & 5001 & 25000 & 900 \\
\hline & & 25001 & 50000 & 1400 \\
\hline & & 50001 & 100000 & 2000 \\
\hline & & 100001 & 200000 & 3000 \\
\hline & & 200001 & 5000000 & $1,50 \%$ \\
\hline
\end{tabular}

Note: This payment system is a combination of a tiered/banded pricing and a percentage based pricing. Throughout, F CFA (Franc of the African

Financial Community) refers to the local currency. The exchange rate during the survey period was about $500 \mathrm{~F} \mathrm{CFA}=\$ 1 \mathrm{US}$. 
Table A.7. Access to financial services.

\begin{tabular}{|c|c|c|c|}
\hline & Burkina Faso & Sub-Saharan Africa & Low income \\
\hline \multicolumn{4}{|l|}{ Account (\% age $15+)$} \\
\hline All adults & 14.4 & 34.2 & 27.5 \\
\hline Women & 12.6 & 29.9 & 23.9 \\
\hline Adults belonging to the poorest $40 \%$ & 8.9 & 24.6 & 19.4 \\
\hline Adults living in rural area & 13.0 & 29.2 & 24.8 \\
\hline \multicolumn{4}{|l|}{ Financial institution account ( $\%$ age $15+$ ) } \\
\hline All adults & 13.4 & 28.9 & 22.3 \\
\hline \multicolumn{4}{|l|}{ Mobile account (\% age $15+$ ) } \\
\hline All adults & 3.1 & 11.5 & 10.0 \\
\hline \multicolumn{4}{|l|}{ Domestic remittances in the past year (\% age $15+$ ) } \\
\hline Sent remittances & 18.5 & 28.7 & 18.3 \\
\hline Receive remittances & 26.7 & 37.2 & 25.6 \\
\hline \multicolumn{4}{|l|}{ Savings in the past year ( $\%$ age $15+)$} \\
\hline Saved at a financial institution & 8.7 & 15.9 & 9.9 \\
\hline Saved using a savings club or person outside the family & 18.0 & 23.9 & 16.3 \\
\hline Saved any money & 50.8 & 59.6 & 46.5 \\
\hline Saved for a farm or business & 15.3 & 22.7 & 16.7 \\
\hline
\end{tabular}

